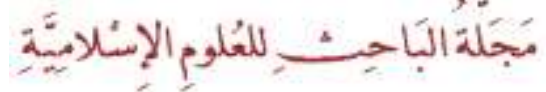

Researcher Journal For Islamic Sciences

Published by the College of Islamic Sciences at the University of Fallujah

ISSN p.p:2708-3993 / ISSN 0.l: 2708-4000

Vol;1- Issue;1/ (2020-2021)

\section{Stop Signs In The Prophet City And Iraqi \\ Qur'ans And Its Impact On Interpretation Surat Al-Kahf As A Model}

Assistant teacher: Hamid Hussein Matar/ University of Fallujah /

College of Islamic Sciences/ hamid-hussienmatar@uofallujah.edu.iq/ 07500181747

Abstract: Learning to read the holy Qur'an and to know the rules of recitation is one of the greatest closeness with which a Muslim gets close to Allah, the Blessed and Exalted be He, and knowing the places of the Stop Signs is a very important matter for the reader of the Qur'an because of its great impact on knowing the meanings that Allah Almighty wanted from the noble verses. Therefore, I chose it to be the title of my research, so the study was based on books of interpretation, readings, stop and initiation books. The research included an introduction and four sections. Introduction: Defining the stop in language, terminology, and its importance. The first topic: Determining the places of stop and setting its signs.

Keywords:(Interpretation,Impact,StopSigns,SuratAlKahf) 


\section{علامات الوقف في مصحفي المدينة النبوية والعراقي وأثرها في التفسير سورة الكهف أنموذجاً}

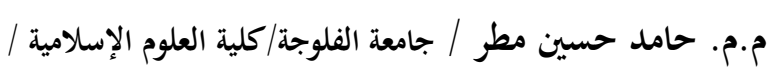
.vo... A IV $\leqslant$ V/hamid-hussienmatar@uofallujah.edu.iq

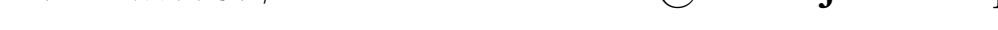




\section{علامات الوقف في مصحفي المدينة النبوية والعراقي وأثرها في التفسير سورة الكهف أنموذجاً \\ جامعة الفلوجة/كلية العلوم الإسلامية}

المقدمة

الحمد لله رب العالمين وأفضل الصلاة والسلام على المبعوث رمة للعالمين سيدنا يُّة وعلى آله وصحبه أمععن،

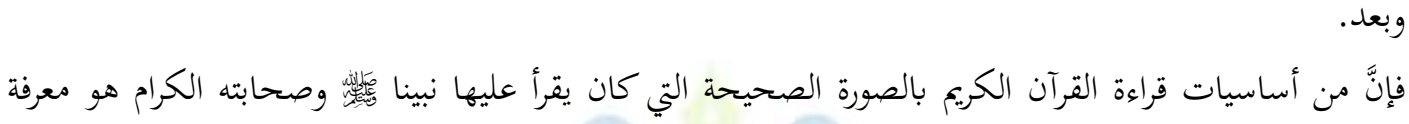

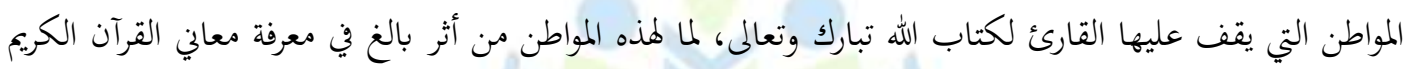

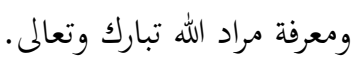
لذلك فإِنَّ اصحاب البني يتعلمون قراءته. وقد اعتمدت في كتابة بكثي هذا على مراجع ومصادر عديدة، منها كتب التفسير والقراءات وكتب الوقف والابتداء

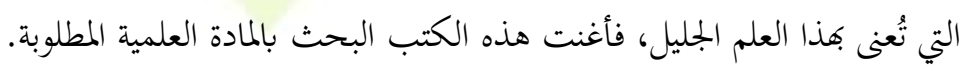

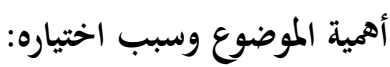

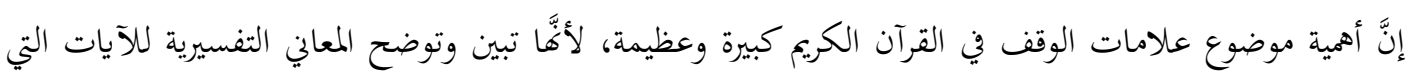

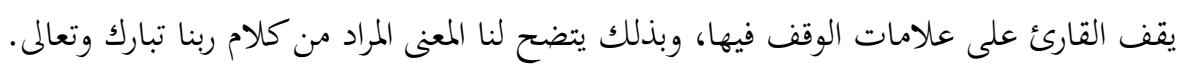

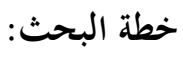

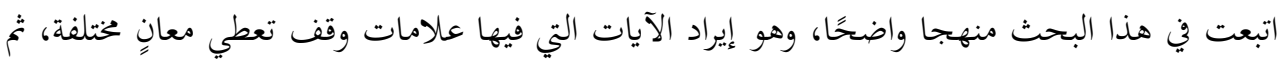

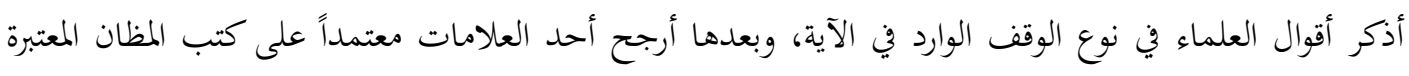

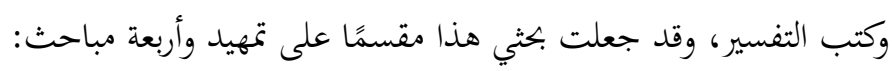
التهيد: ذكرت فيه تعريف الوقف في اللغة والاصطلاح وأقسام الوقف وأهمينه. 纟o1 
والمبحث الأول: فذكرت فيه الوقوف على مواطن الوقف ووضع علاماته.

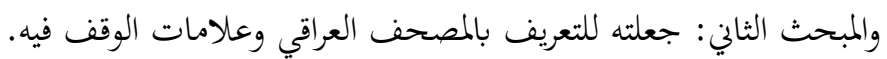

والمبحث الثالث: جعلته للتعريف بمصف المدينة وعلامات الوقف فيه.

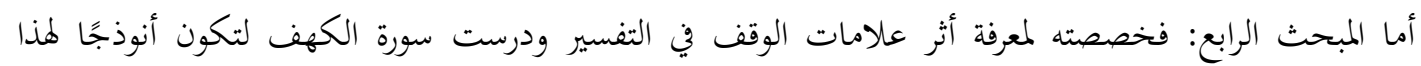

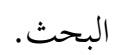

ثم الخاتمة: وذكرت فيها نتائج البحث وأهم ما توصلت اليه فيه.

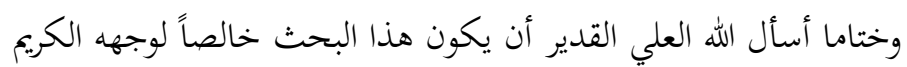

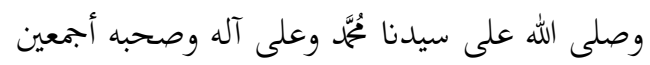




\section{تََهريد \\ أولاً: تعريف الوقف}

الوقف في اللغة: هو الحبس والكفُُ(1)، تقول: أوقفت عن الأمر الذي كنت فيه، أي: أقلعت(r)، وفي القراءة: هو

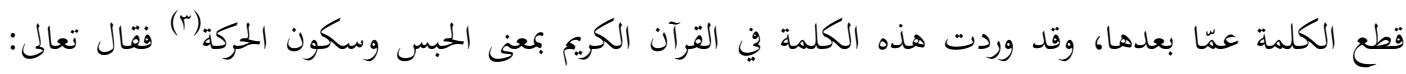

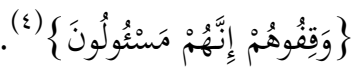

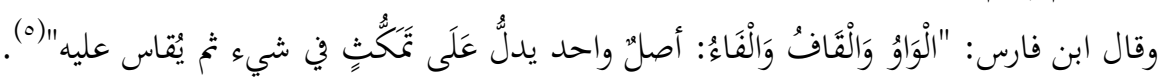

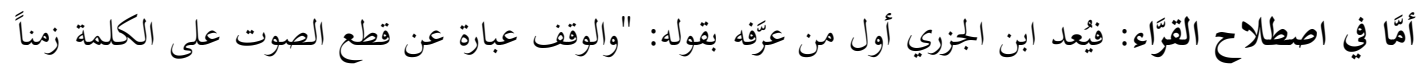

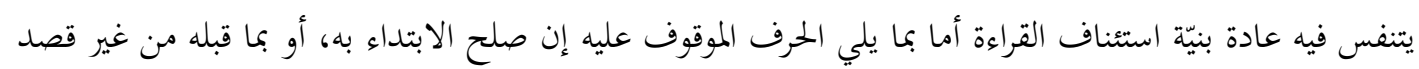

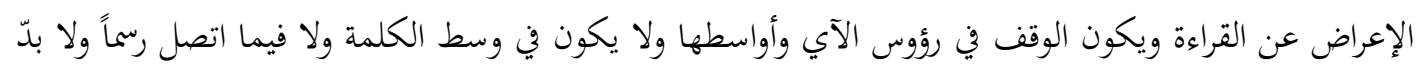
من التنفّس معه" (T). كما عرفه الأشثولي بقوله: "قطع الصوت آخر الكلمة زمنًا ما، أو هو قطع الكلمة عما بعدها، والوقف والقطع

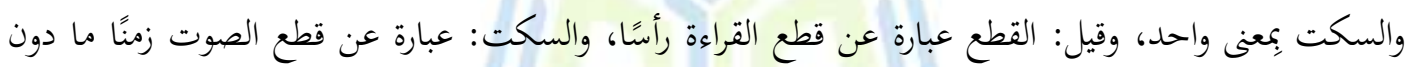

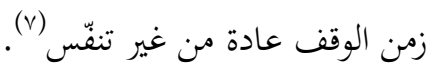

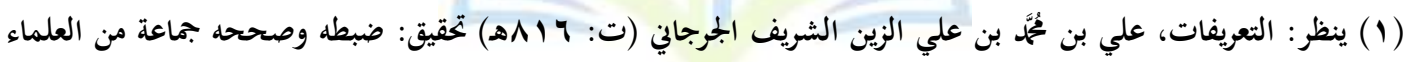

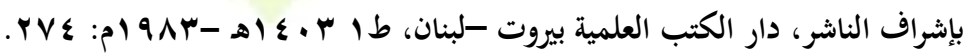

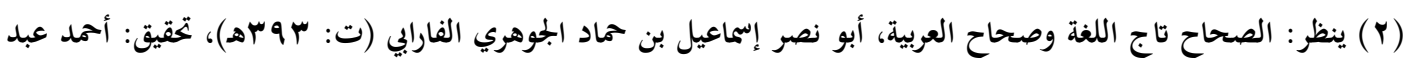

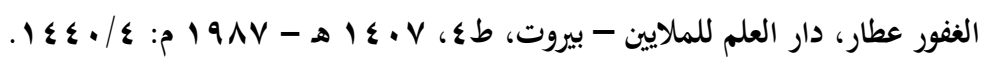

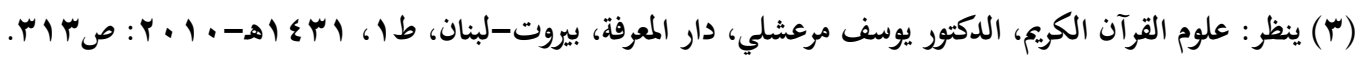

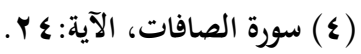

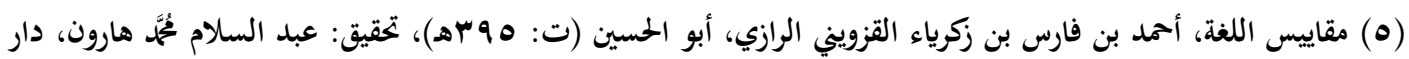

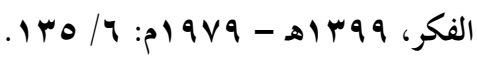

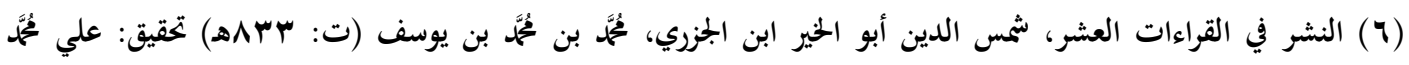

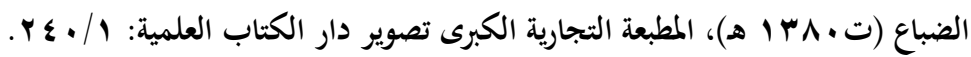

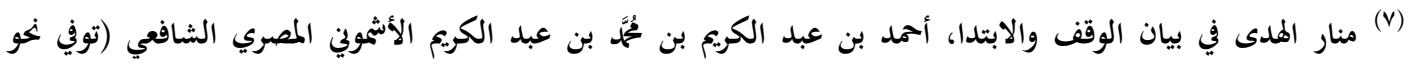

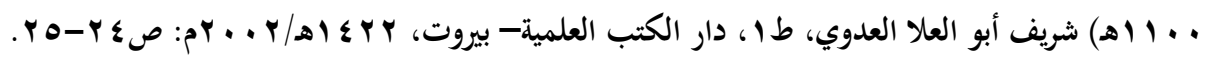
$\leq 7$. 
وعرفه العلماء الحمدثون فقالوا: "هو قطع الصوت عند آخر الكلمة القرآنية زمناً يسيراً يتنفس فيه عادة مع قصد المعا

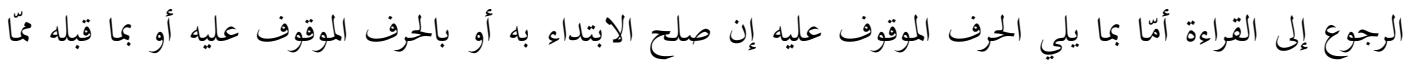

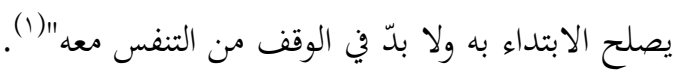
ولا فرق بين تعريف القدماء والمحدثين، فقد اتفقوا على تقييده بالزمن، والمقصود هو الزمن اليسير.

ثانيًا: أقسام الوقف: ليس هناك تقسيمٌ منضبطُ مصصورٌ بعدد معين للوقف فقسَّمه بعضهم على قسمين اختياري واضطراري؛ لأنَّ الكلام إما أن يتم، أو لا (†) وقسمه آخرون على ثلاثة أقسام: تام، وقبيح، وحسن ، فالتام: الذي يحسن الوقف عليه والابتداء بما بعده، الذاء

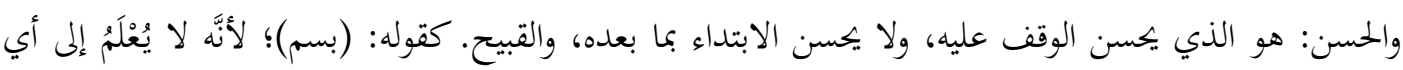
شيء أضفته (r). وذكر غيرهم أنَّ الوقف في القرآن على ثمانية أقسام: تام وشبيه به وناقص وشبيه به وحسن وشبيه به، وقبيح وشبيه ب ب) وأكثر العلماء على أنَّه على أربعة اقسام (o) ا. الوقف التام: هو ما يحسن السكوت عليه ولم يكن له تعلق بما بعده ولا بما قبله لا لفظأ ولا معنى، مثال

(1) منار أحكام قراءة القرآن للشيخ محمود خليل الحصري، سلسلة دراسات في الإسلام، طبعة الجلس الأعلى للشؤون

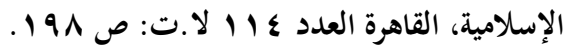

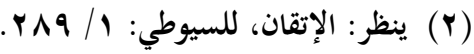

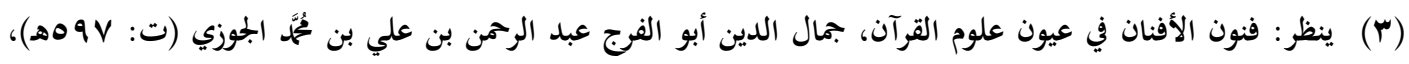

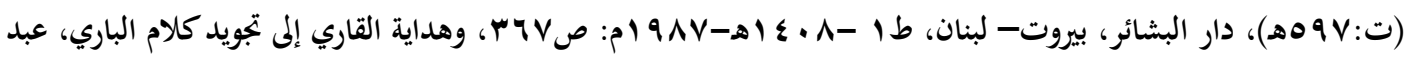

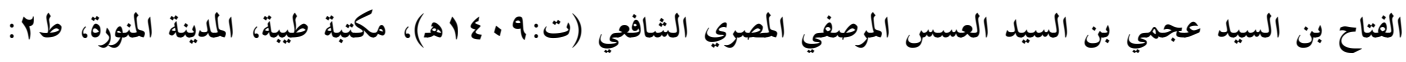

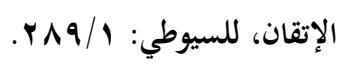

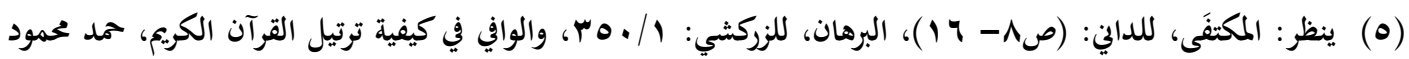
纟า

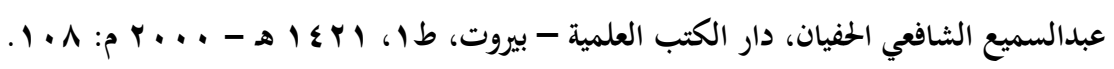


ذلك قوله تعالى: $\}$

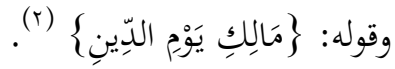

r. الوقف الكافي: هو أن تقف على كلمة ليس لها تعلق بما بعدها، ولا بما قبلها في اللفظ، بل بالمعنى،

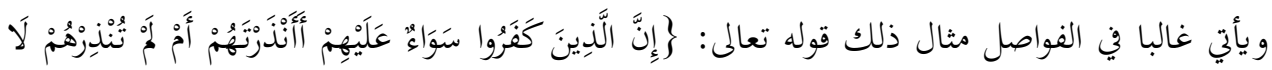

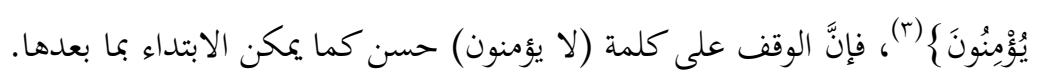

r. الوقف الحسن: هو أن تقف على كلمة لها تعلق بما بعدها، أو بما قبلها لفظا ومعنى مثال ذلك قوله بونه

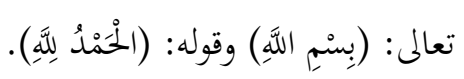

ع. ـ الوقف القبيح: هو أن تقف على كلمة لا يتم الكلام به، كالوقوف على المبتدأ دون خبره، أو على له الفعل دون فاعله، وأقبح من ذلك الوقف على ما يوهم وصفا لا يليق بذات الله تعالى كأن يقف على

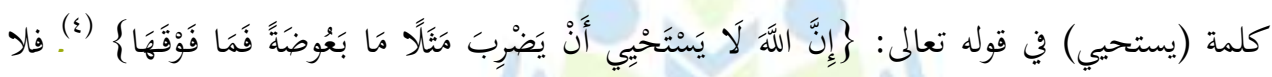
يجيوز الوقف إلا لضرورة، ثم يعيد الكلمة التي وقف عليها إذا لم تغير المعنى، وإلا أعاد ما يحسن البدء به. بهاب.

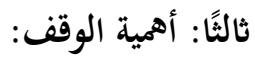

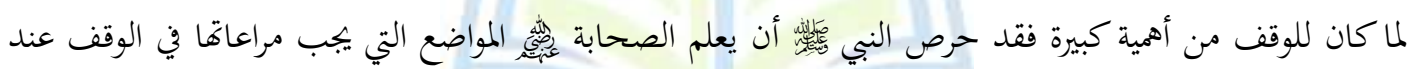

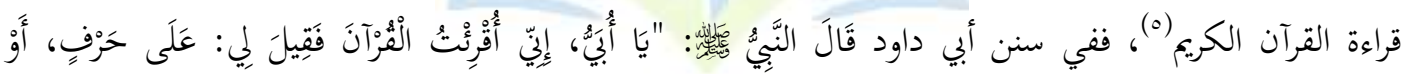

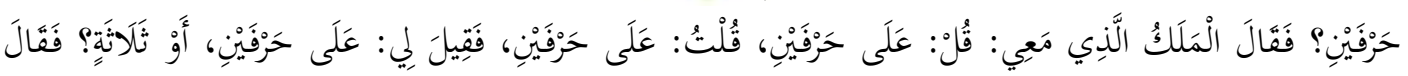

$$
\begin{aligned}
& \text { (1) سورة البقرة، الآية: ه. } \\
& \text { (ץ) سورة الفاتحة، الآية: ع. } \\
& \text { (ז) سورة البقرة، من الآية: } 7 .
\end{aligned}
$$

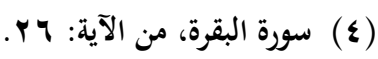

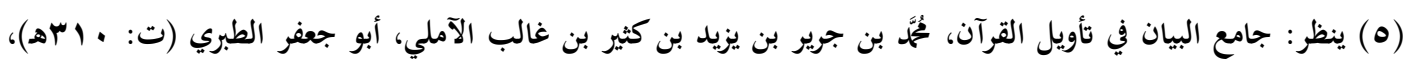

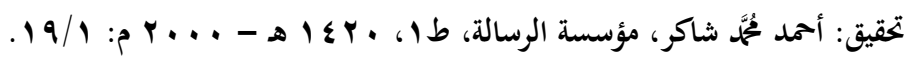
纟Tr 


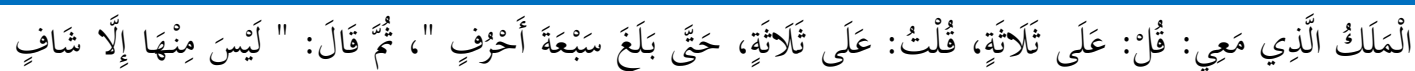

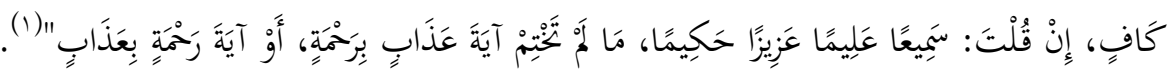

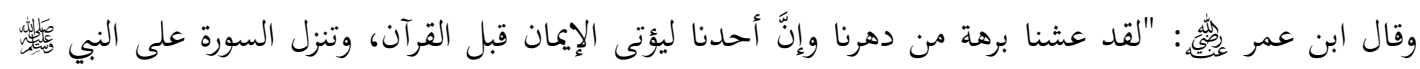

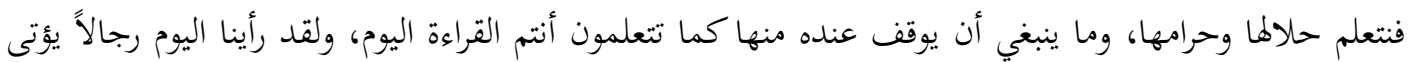

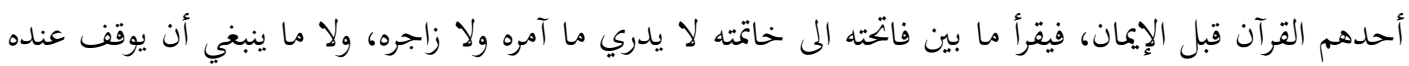

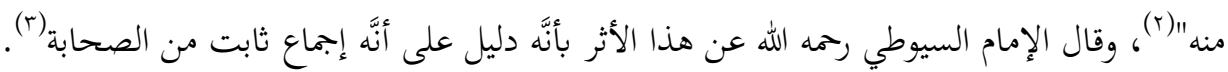

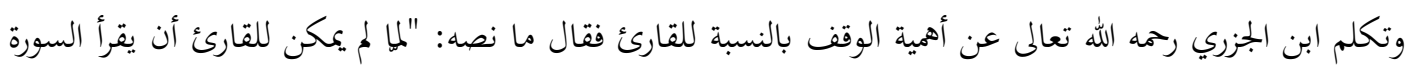

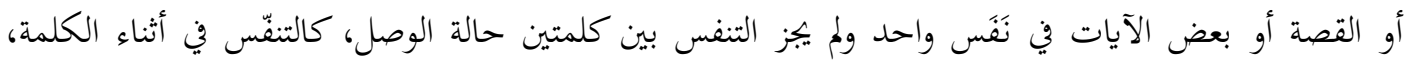

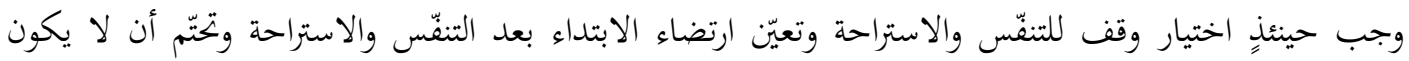

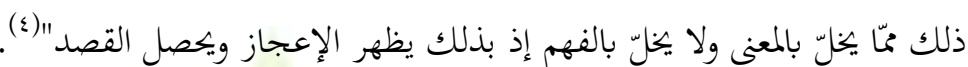

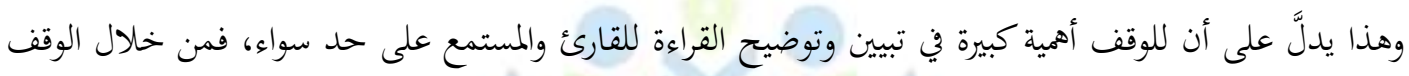

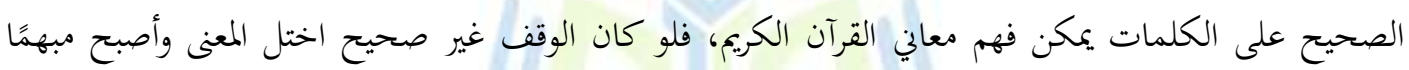

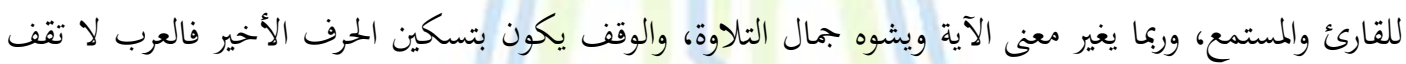
على متحرك (o) رابعًا: مواطن الوقف من عهد الرسول كئس إلى تاريخ تدوينه:

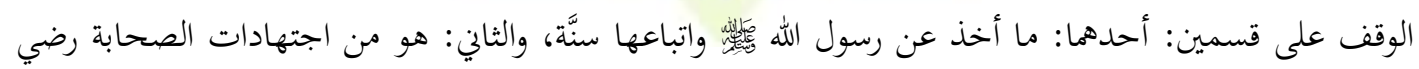
الله عنهم، والتابعين ومن جاء بعدهم، والوقف عليها بحسب ما ماتئ يظهر المعنى الكامل.

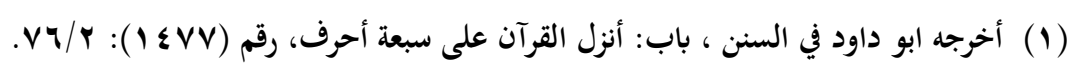

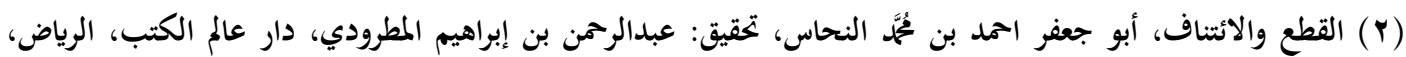

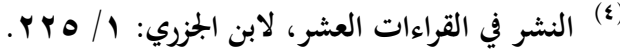

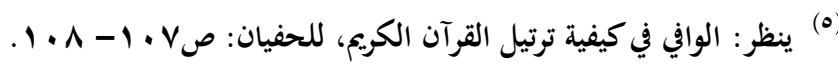


القسم الأول: مأ أخذ عن رسول الله

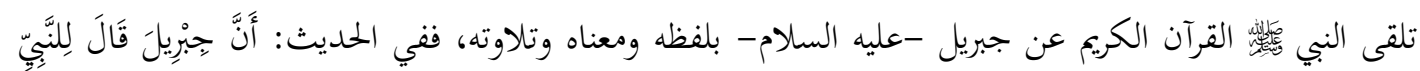

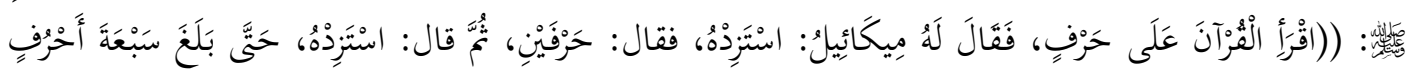

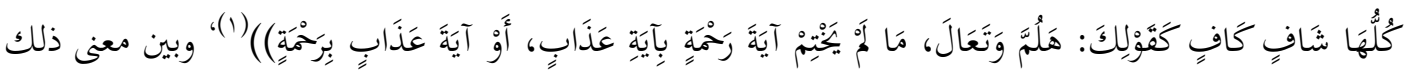

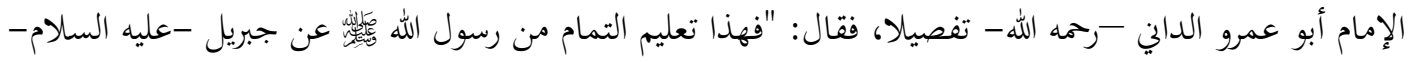

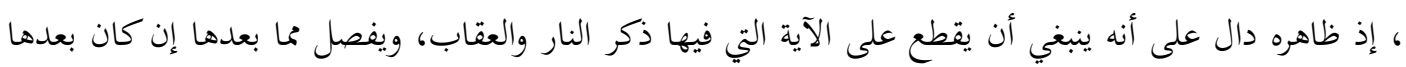

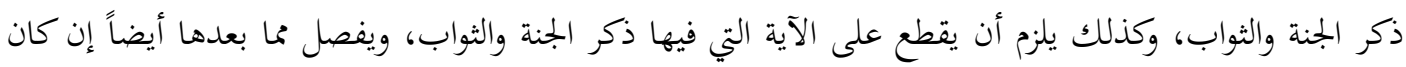

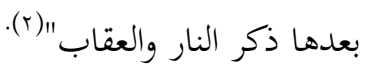

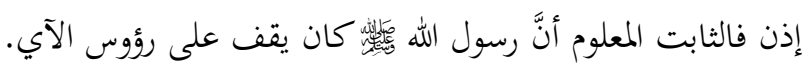

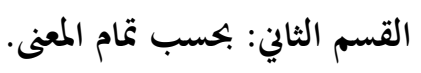

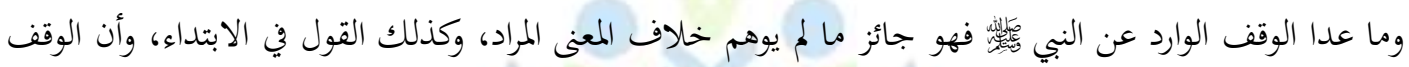

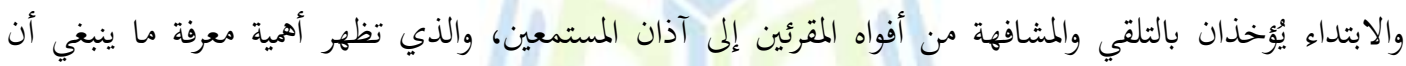
يوقف عنده منها وما لا يوقف (r).

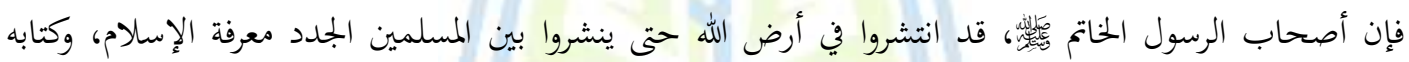

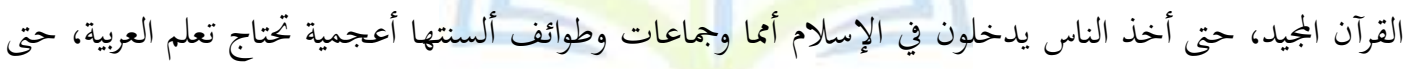

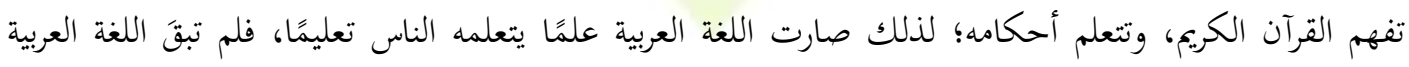

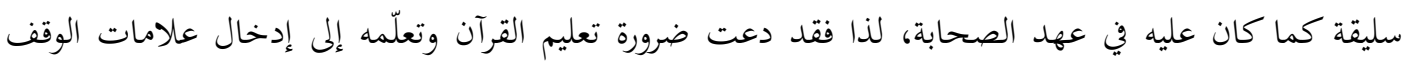

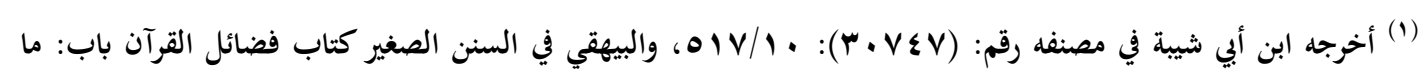

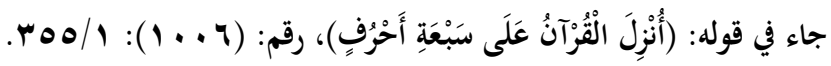

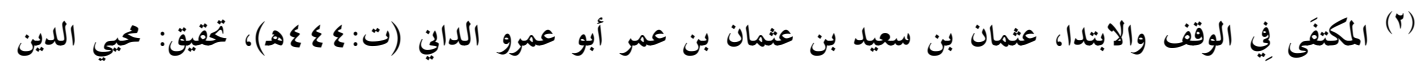

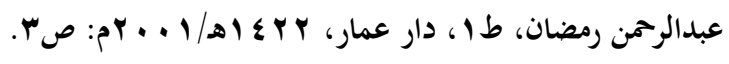

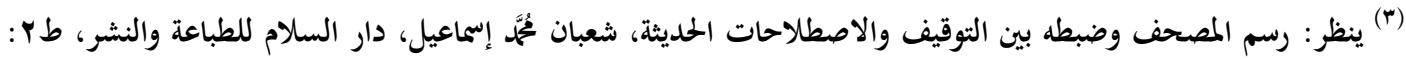

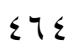


لضبط معاني القرآن من حيث الوقف على معنى، والابتداء بمعنى جديد مستقل، لتسهيل عملية الفهم والإعراب

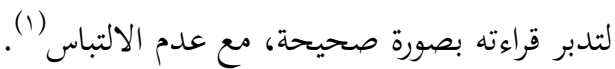

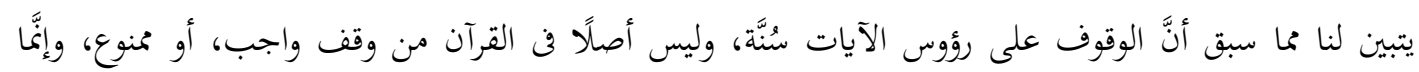

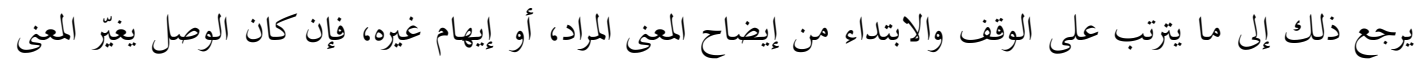
لزم الوقف، وإن كان الوقف يغير المعنى لزم الوصل. خامسًا: حكم التزام القارئ بعلامات الوقف:

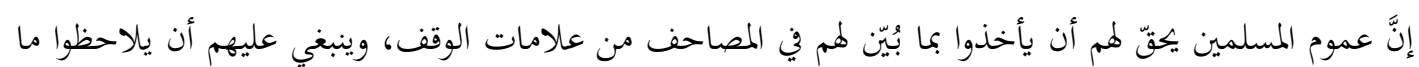

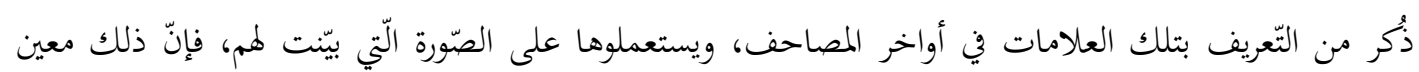

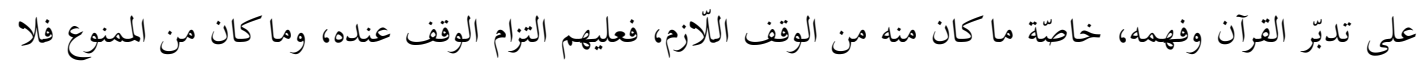

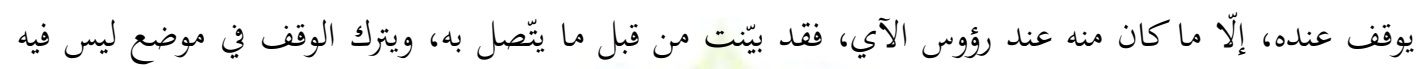
علامة وقف أصلا (r). ولا يستثنى من هذا إلّا من أوتي حظّا من فهم القرآن، وعدّة واقية من الخطأ في ضبط المعنى، من أهل العلم والذّكر، فهؤلاء قد يستحسنون مواضع للوقف باجتهادهم في تدبّر القرآن.

(1) ينظر : دراسات في علوم القرآن الكريم، أ. د. فهد بن عبد الرحمن بن سليمان الرومي، حقوق الطبع محفوظة للمؤلف، وها،

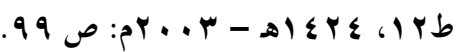

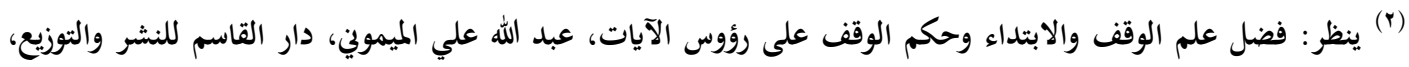

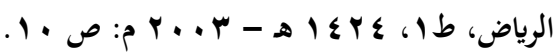
ร70 


\section{المبحث الأول: الوقوف على مواطن الوقف ووضع علاماته}

دعتِ الضرورة إلى إدخال علامات الوقف والابتداء؛ لتوفير إمكانية فهم معاني القرآن العظيم، فقالوا: "إن معرفة

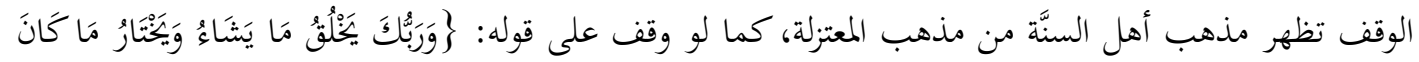

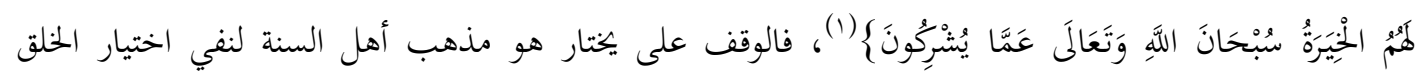

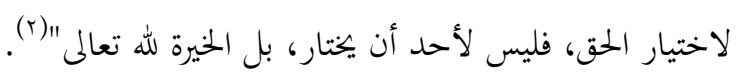

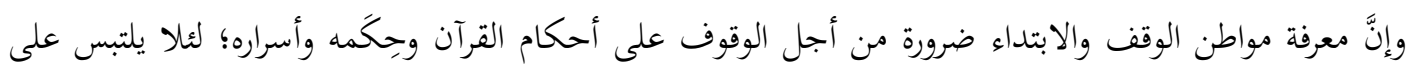

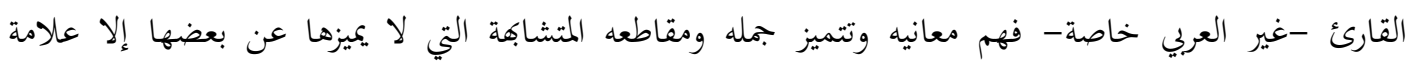

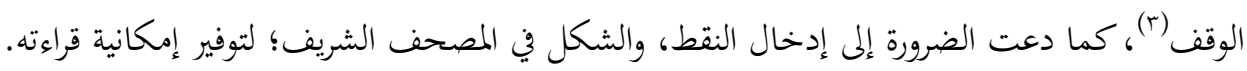

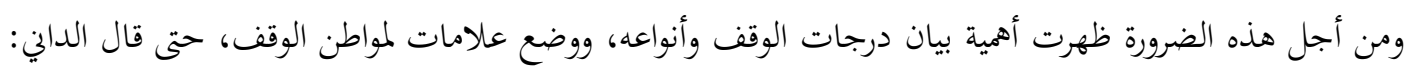

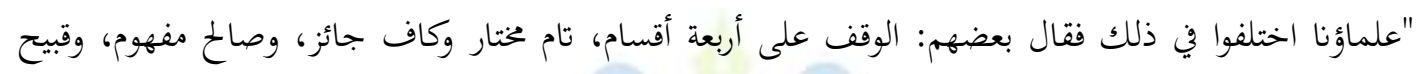

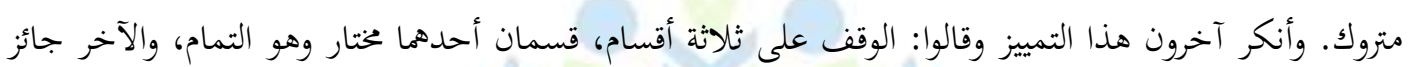

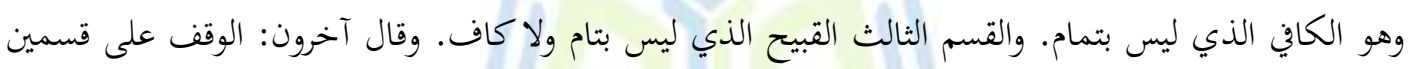

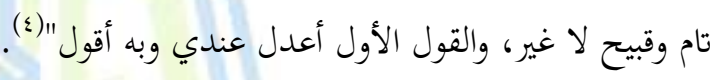

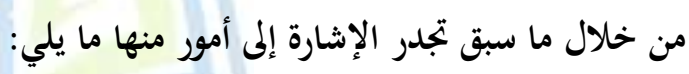

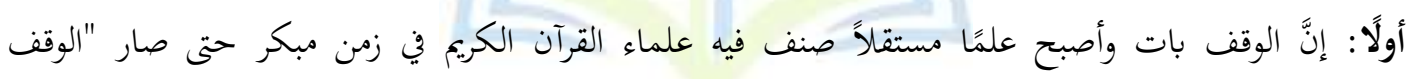

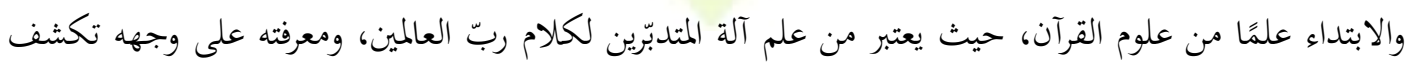

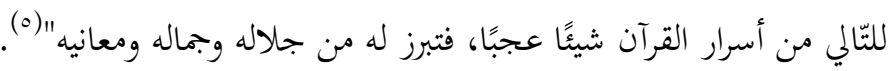

$$
\text { (1) (1) سورة القصص، الآية: } 11 \text { (1). }
$$

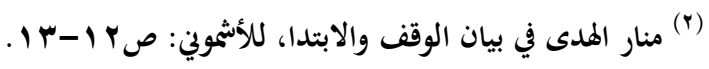

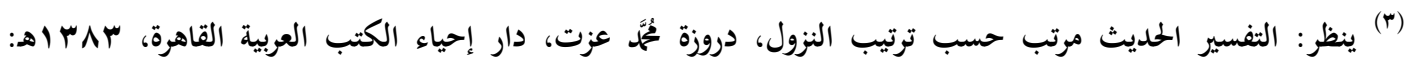

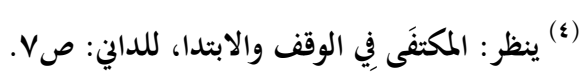

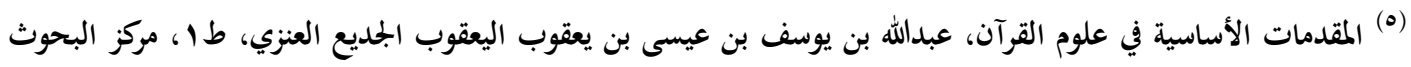

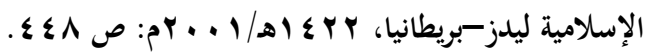


ثانيًا: إنَّ اختلاف أسماء أنواع هذه الوقوف لا يضرّ؛ لأنَّ اتفاق القراء على معاني الوقف قائم على ذائقة القارئ، ومدى فهمه، وتدبره لمواطن الوقف والابتداء لآي القرآن الكريم.

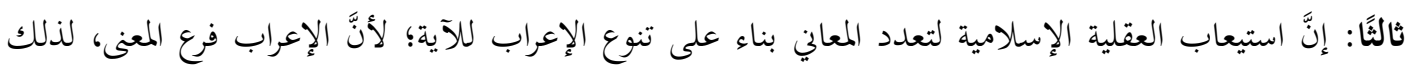

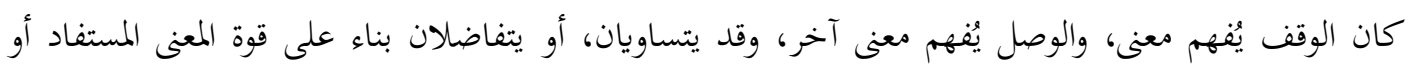

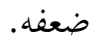

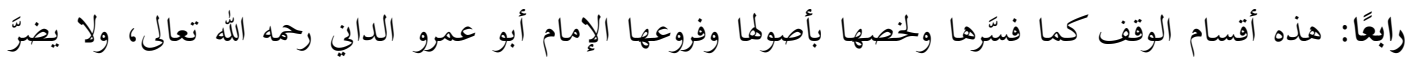

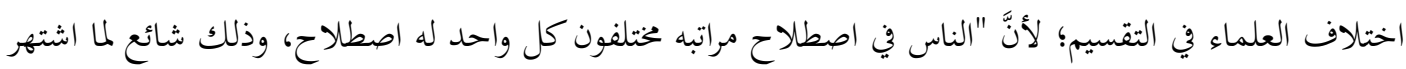

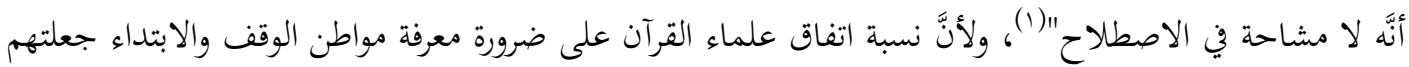

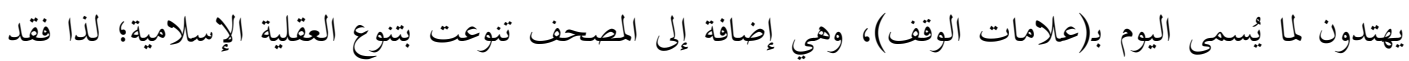

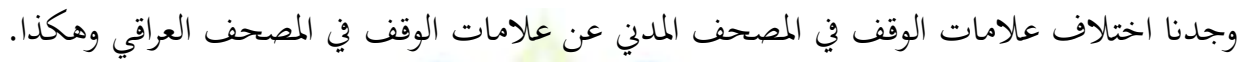

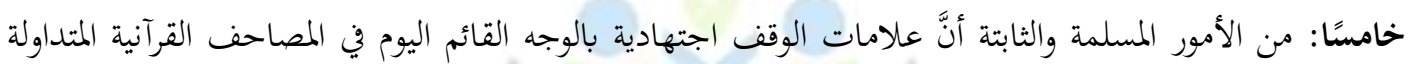

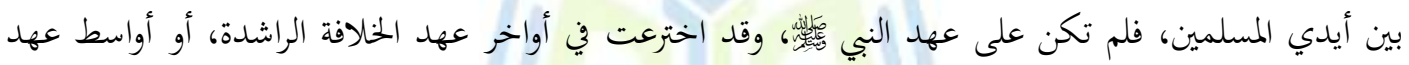

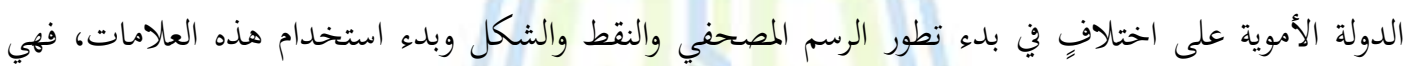

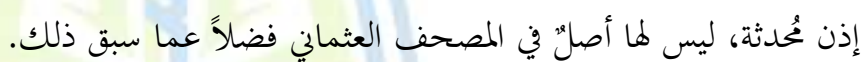

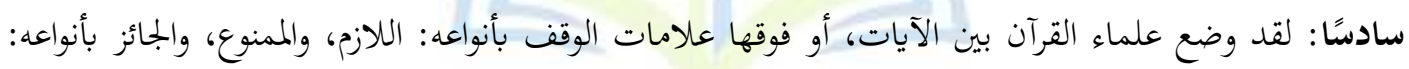

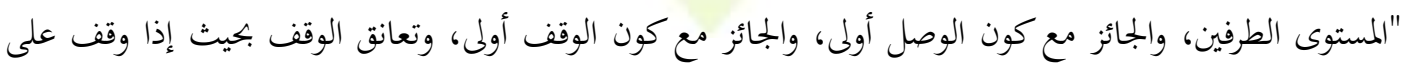
أحدهما لم يقف على الآخر" (r). كذلك فإنَّ وضع علامات الوقف والمد، وغيرها على الحروف كل ذلك ملك مستحدَث، وفيه كلامٌ طويلٌ للعلماء من

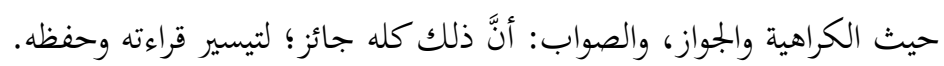

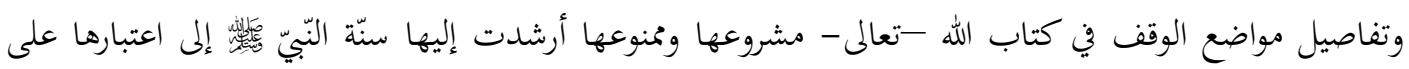

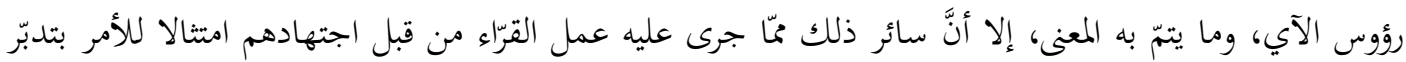

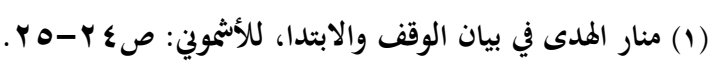

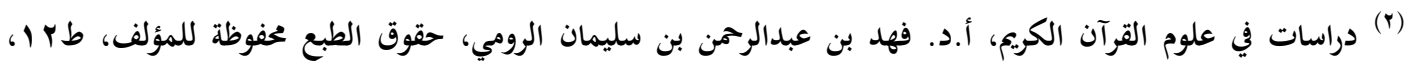

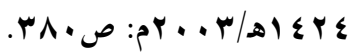
纟ัท 
القرآن، وربّما دخل في ذلك شيءّمّا تلقّوه بأسانيدهم في القراءة، فقوهم: (وقف جائز، وممنوع، ولازم)، وشبه ذلك تسميات لما استعملوه من ذلك، وجرى عملهم عليه (1)

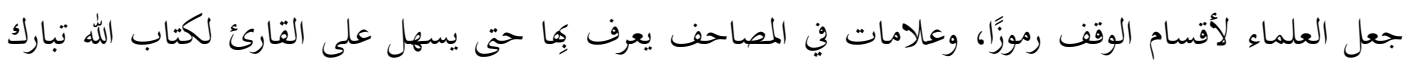

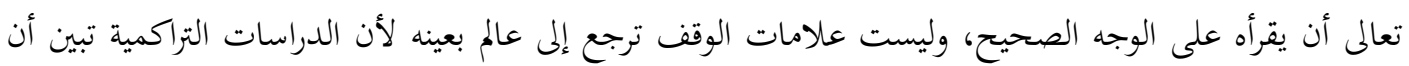

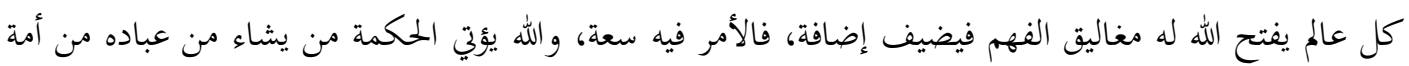
خاتم النبيين

\section{المبحث الثاني: تعريف بالمصحف العراقي وعلامات الوقف فيه}

المصحف العراقي له منهجيته الواضحة في رسم كلماته، وعدّ آياته، وبيان مواضع الوقف والابتداء، فقد جاء بيان

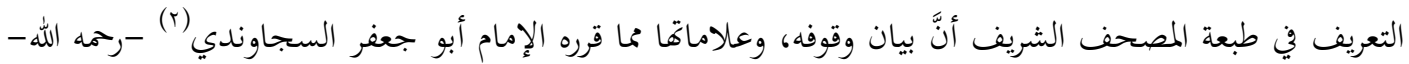

علامات الوقف في المصحف العراقي: 1. (م): علامة الوقف اللازم: وهو الذي يتعين فيه الوقف، ولا يجوز الوصل عنده. r. (ط): علامة الوقف المطلق: وهو ما يحسن الابتداء بما بعده. r. (ج): علامة الوقف الجائز: وهو الذي يستوي فيه الوقف والوصل. ع. (ز): علامة الوقف المجوز : وهو ما يبوز فيه الوقف والوصل، ولكن الوصل أولى.

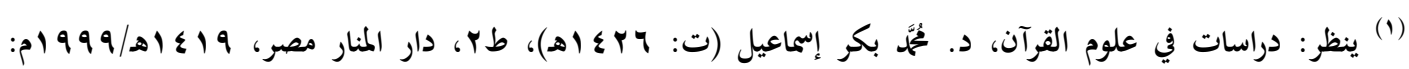

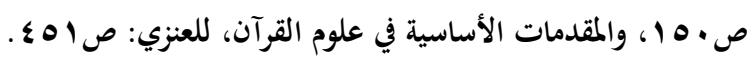

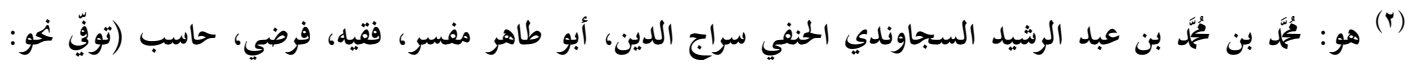

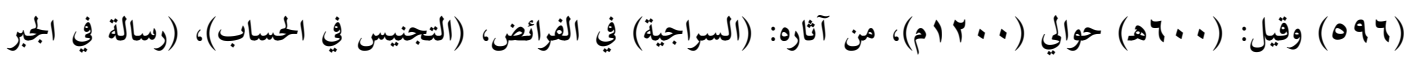

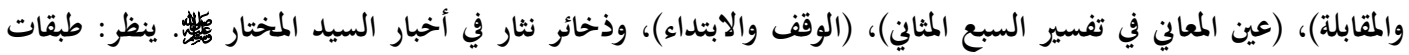

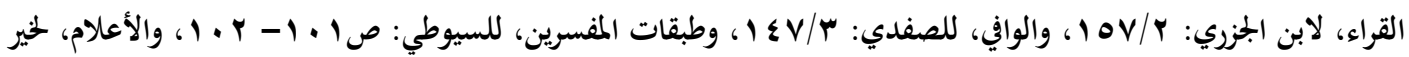

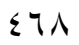

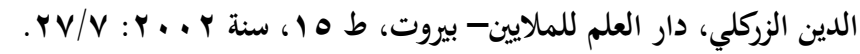

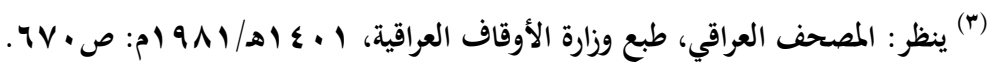




$$
\begin{aligned}
& \text { ه. (ص): علامة الوقف المرخص: هو الذي يرخص فيه الوقف للضرورة. } \\
& \text { T. (ق): علامة الوقف الذي قال به بعض العلماء. } \\
& \text { V. (قف): علامة الوقف المستحب، ولا حرج في الوصل. } \\
& \text { ^. (لا): علامة عدم جواز الوقف إلا عند الفاصلة، فيستحب الوقف عند الأكثرين. } \\
& \text { 9. (ك): علامة الوقف الجاري على حكم الوقف السابق('). } \\
& \text { ويُلاحظ على تلك العلامات ما يلي: }
\end{aligned}
$$

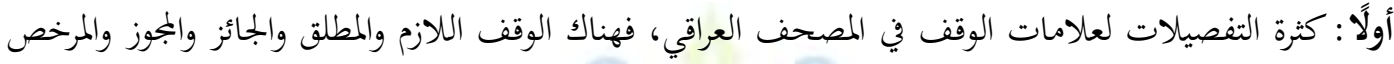

ثانيًا: تداخل بعضها في بعض كتداخل الوقف المستحب وعلامته (قف) في الوقف المجوز وعلامته (ز) لاتفاقهما

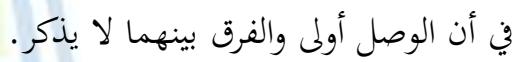
ثالثًا: ابتكار أنواع جديدة من أنواع الوقف، مثل النوع المرموز له بـ (ك) الدال على الوقف الجاري على حكم الوقف

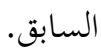




\section{المبحث الثالث: تعريف المصحف المدلي وعلامات الوقف فيه}

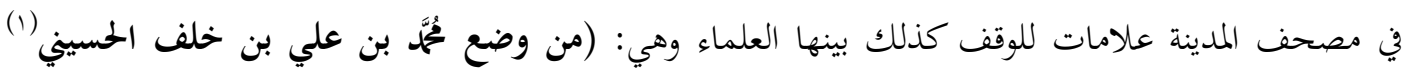

$$
\begin{aligned}
& \text { وغيره)(r)، وفيما يلى بيان لهذه العلامات ومدلولاتحا. } \\
& \text { علامات الوقف في المصحف المدلي: }
\end{aligned}
$$

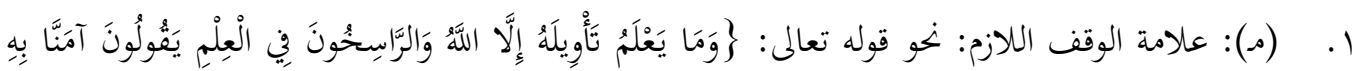

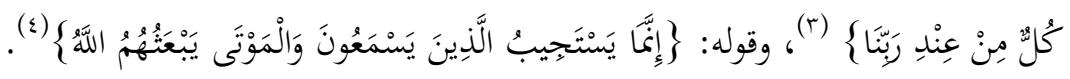

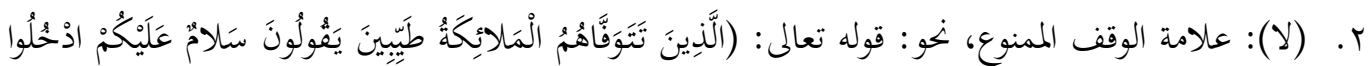

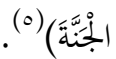

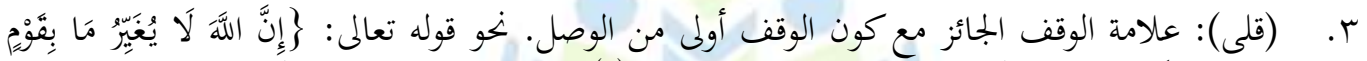

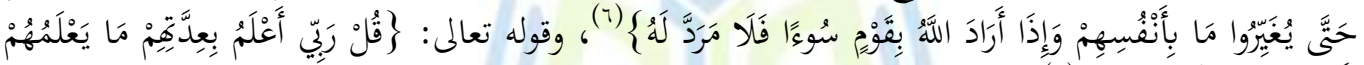

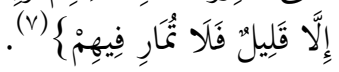

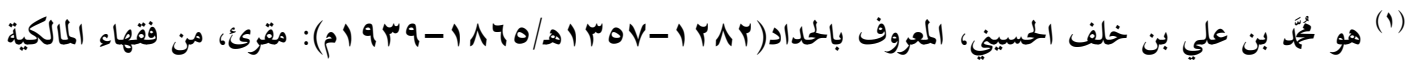

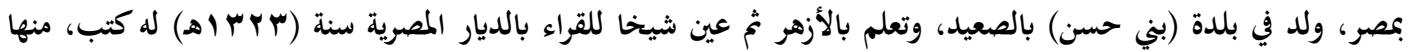

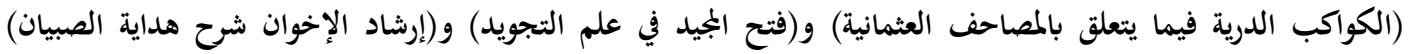

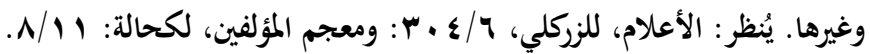

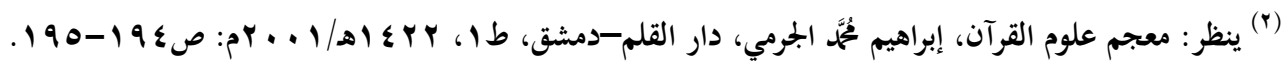

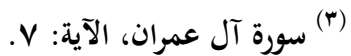

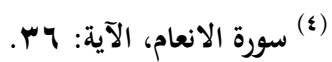

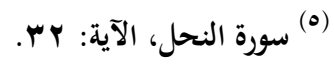

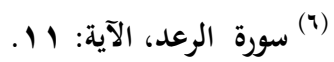
سورة الكهف، الآية: Yr. (v) سورة الآية

$\varepsilon v$. 


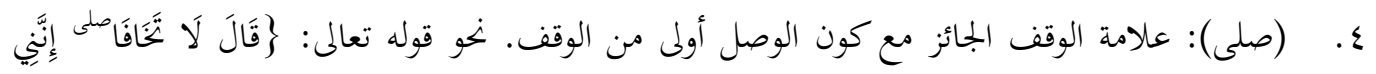

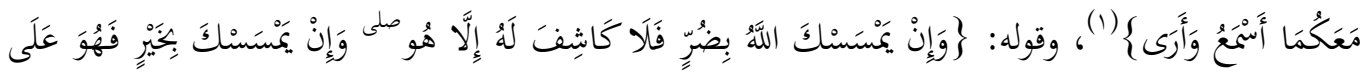

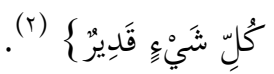

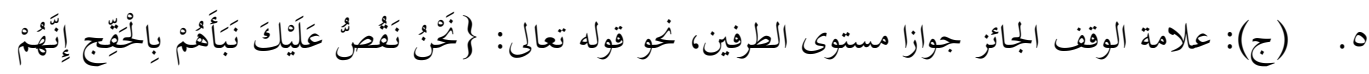

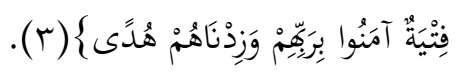
ج. (**): علامة تعانق الوقف بحيث إذا وقف على أحد الموضعين لا يصح الوقف على الآخر، نحو قوله

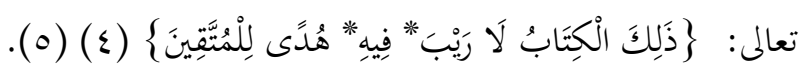
ويُلاحظ على تلك العلامات ما يلي:

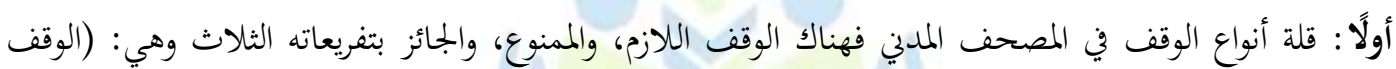

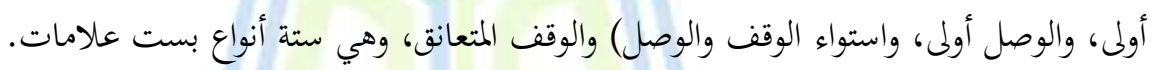

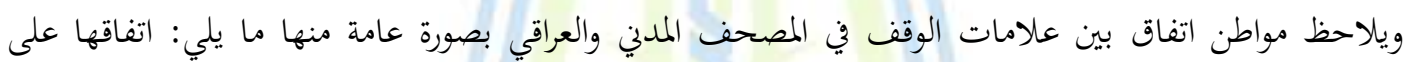
وضع علامات وقف لأربعة أنواع التي رجحها الداني وهي (تام وكافي وحسن وقبيح)، وأهم اتفقوا على الوقف اللازم والممنوع في مواضعما.

$$
\begin{aligned}
& \text { (1) سورة طه: الآية: \؟ }
\end{aligned}
$$

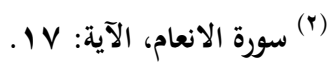

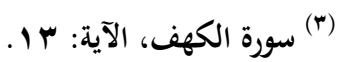

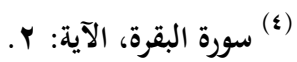

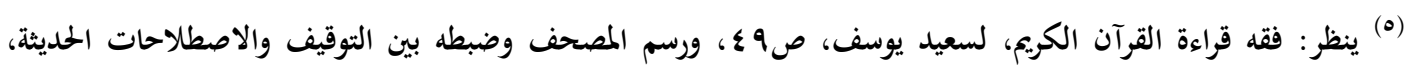

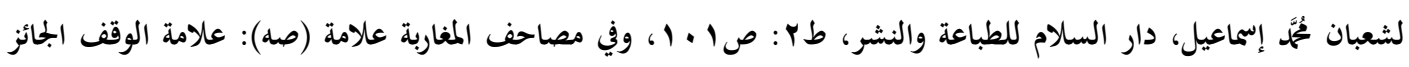

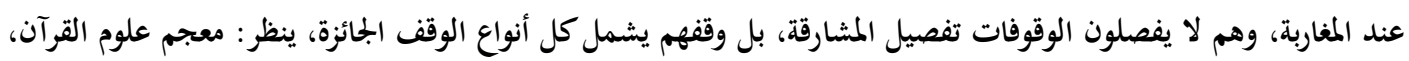
\&v1 


\section{المبحث الرابع: أثر علامات الوقف في التفسير سورة الكهف أنموذجًا المطلب الأول: ظاهرة اختلاف العلامات: المات المات

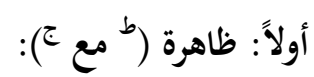

وقد جاءت علامة (ط) في المصحف العراقي بينما جاءت علامة (ع) في مصحف المدينة في سورة الكهف (10)

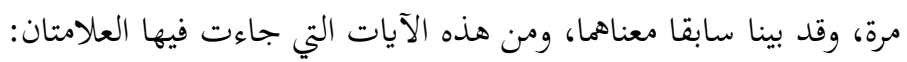

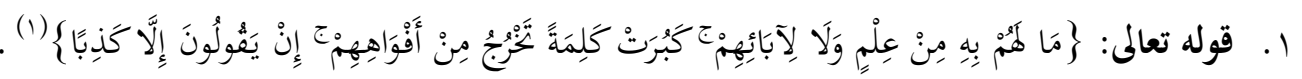

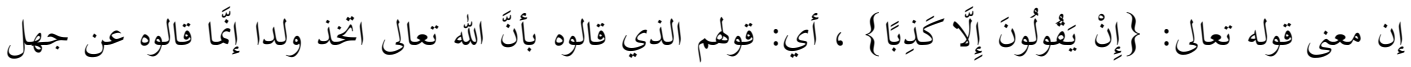

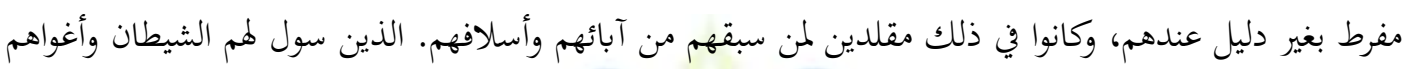
حتى قالوا بهذه الفرية العظيمة(r). فقد تكررت العلامتان في الآية في موضعين وهما قوله: (آبائهم) وقوله: (أفواههم)، وعند الرجوع إلى كتب المظان

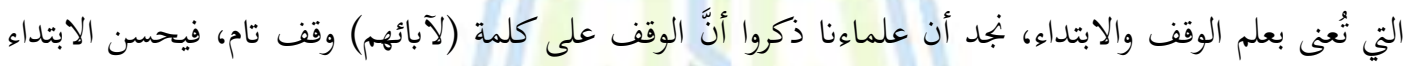

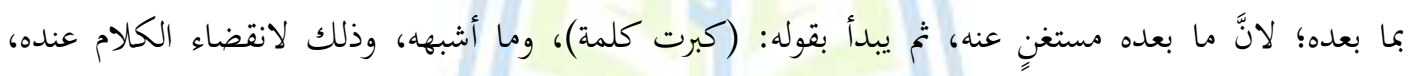

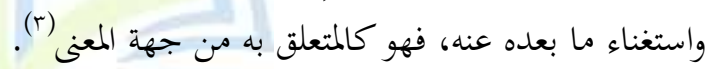

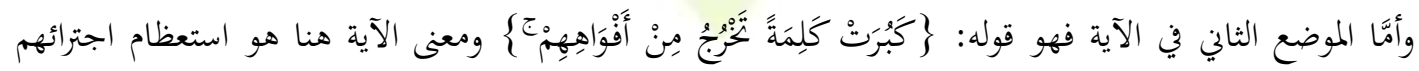

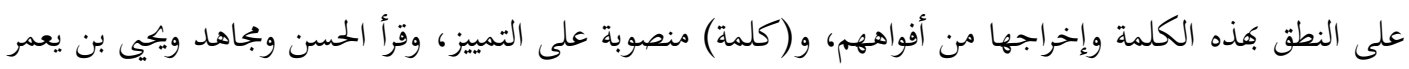

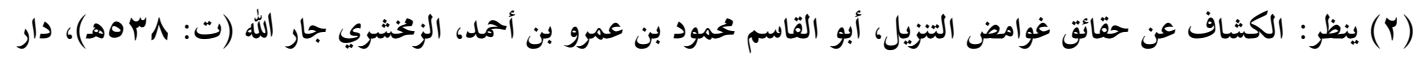

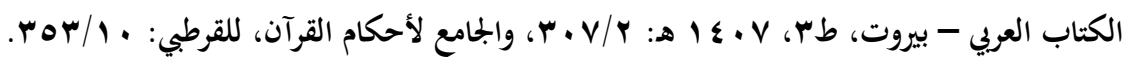
(r) ينظر : المكتفى في الوقف والابتدا، للداني: ص ص ه هـ 9.

$\varepsilon \vee r$ 
Published by the College of Islamic Sciences at the University of Fallujah

ISSN p.p:2708-3993 / ISSN o.I: 2708-4000

Vol;1- Issue;1/ (2020-2021)

وابن أبي إسحاق بالرفع على الفاعلية(1) فلا حاجة للإضمار فيها، والنصب أقوى وأبلغ، فإن فيه معنى التعجب، كأنه قيل: ما أكبرها كلمة (r)

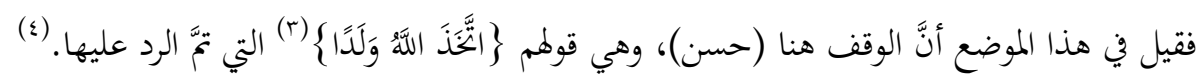

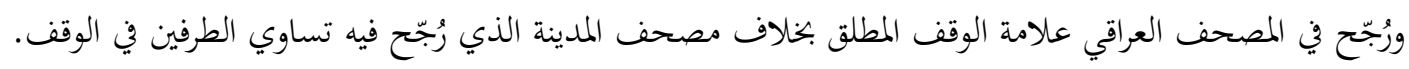

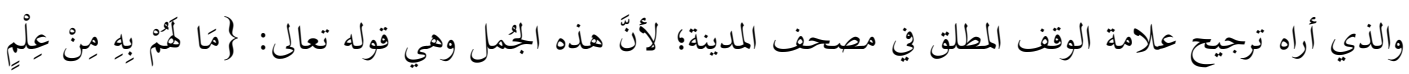

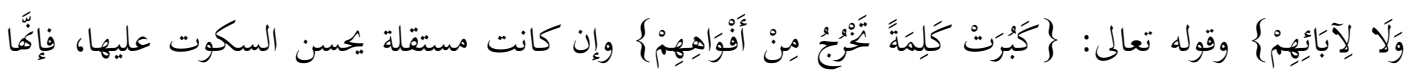

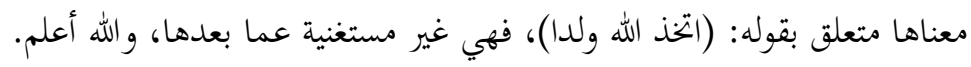

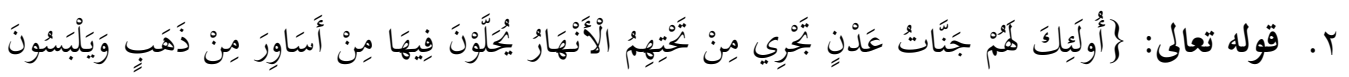

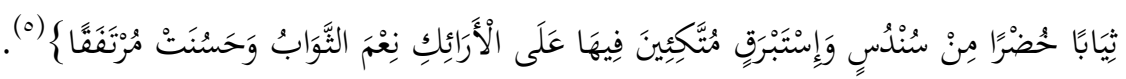

معنى الآية الكريمة أنَّ الله أعلَّ للمؤمنين نعيمًا مقيمًا في الجنَّة، وأنَّ هذه الجنة فيها من الأفهار الجارية والحُلي التي

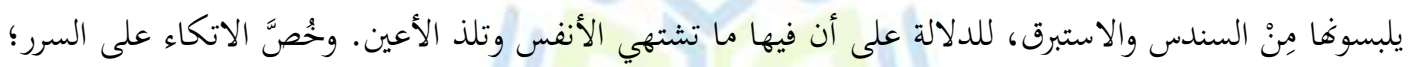

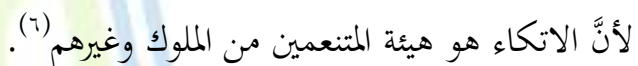

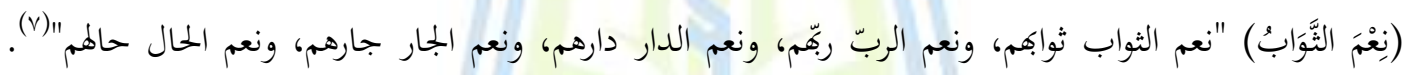

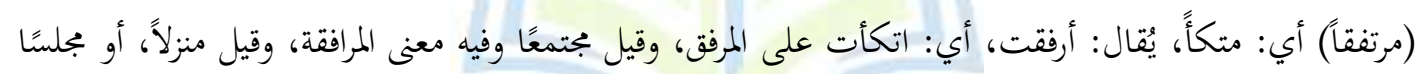

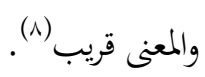

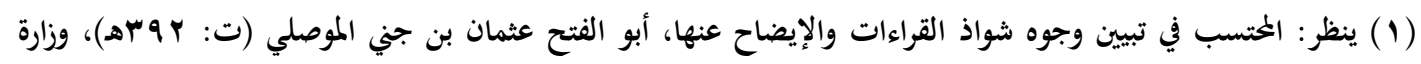

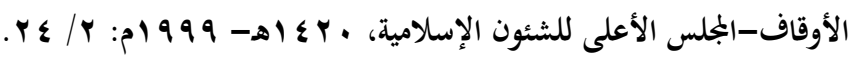

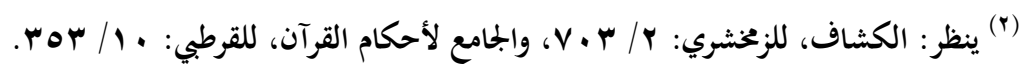

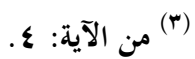

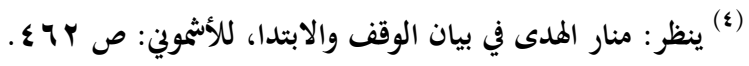

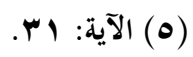

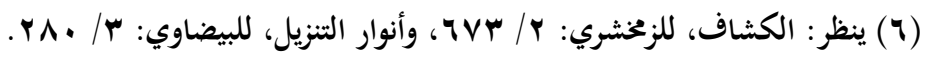

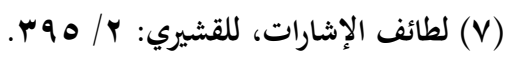

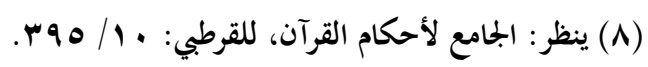
$\sum V T$ 
وقد وضعت علامتا الوقف اللتان نخن بصددهما في هذه الآية الكريمة على كلمة (الأرائك)، وبعد متابعة الوقف في

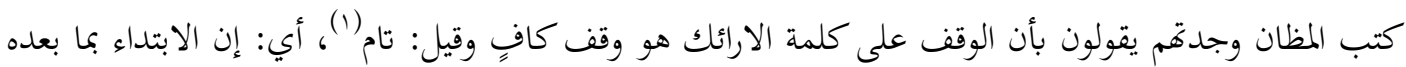

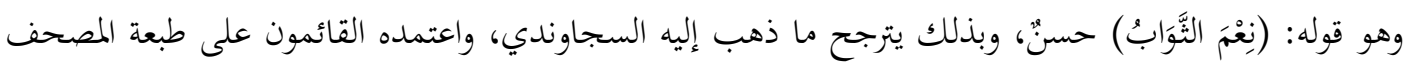

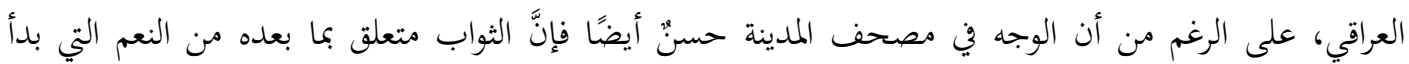
القرآن بسردها والله تعالى أعلم. ثانيًا: ظاهرة (ط مع صلى):

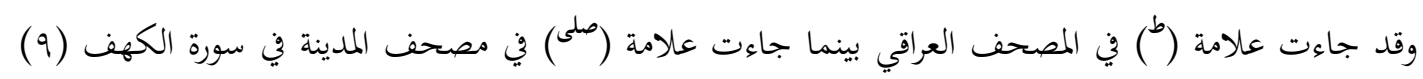

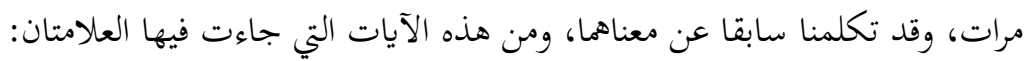

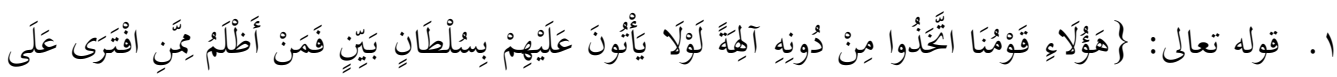

السَِّ كَذِبًا

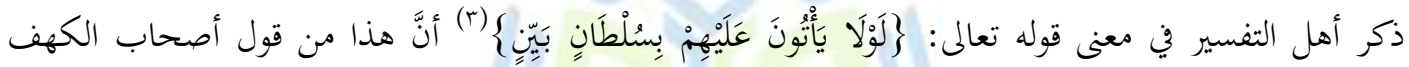

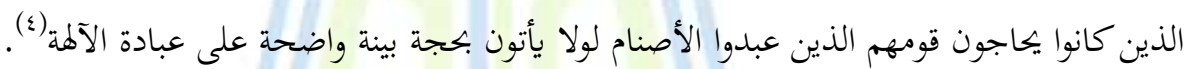

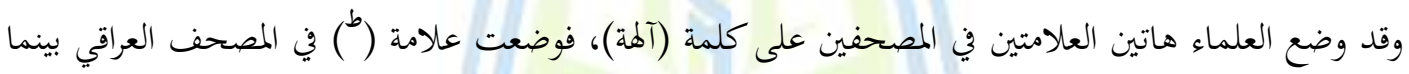
وضعت علامة (صلى) في مصحف المدينة.

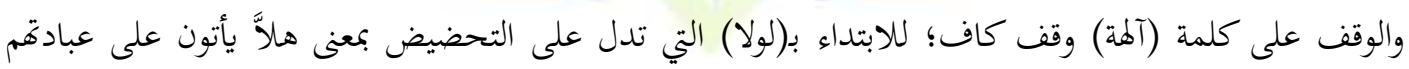

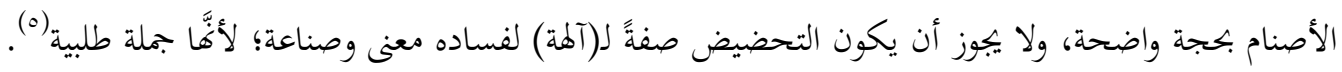

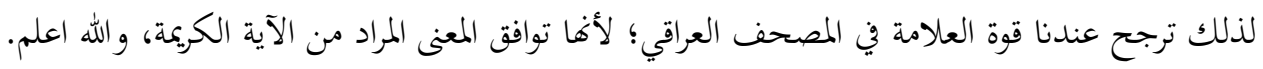

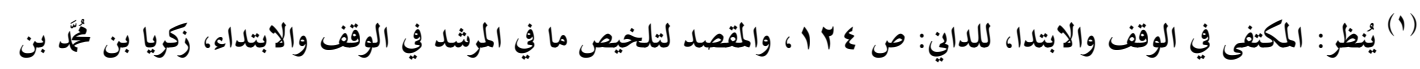

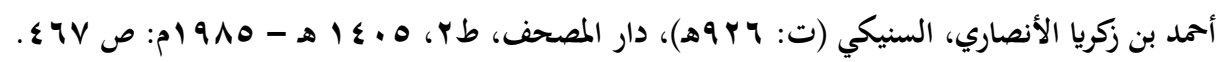

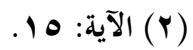

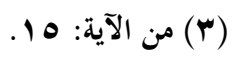

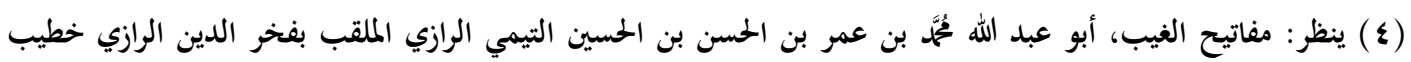

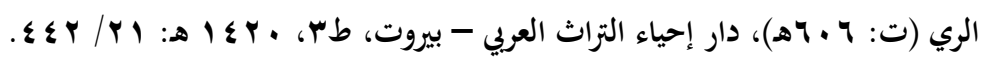

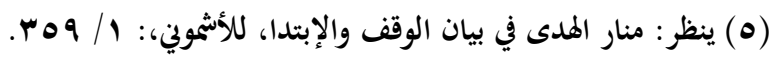
$\varepsilon \vee \leqslant$ 


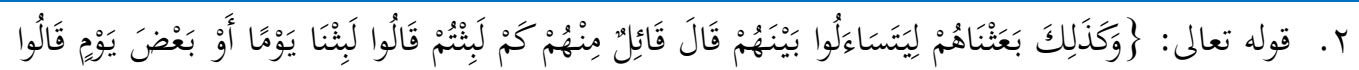

$$
\text { (1) }
$$

تتحدث الآية الكريمة عن أصحاب الكهف، الذين أماقم الله عددًا من السنين فلما أحياهم الله اختلفوا فيما بينهم

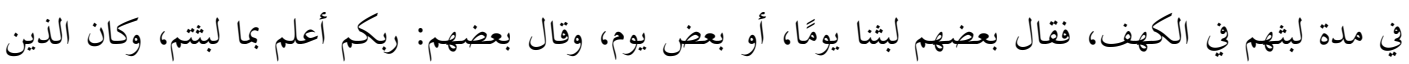

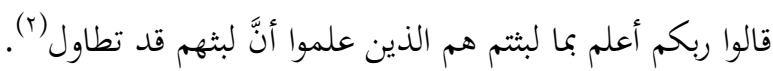

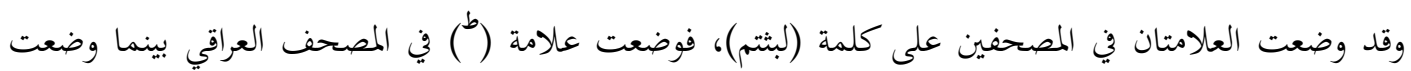
علامة (صلى) في مصحف المدينة.

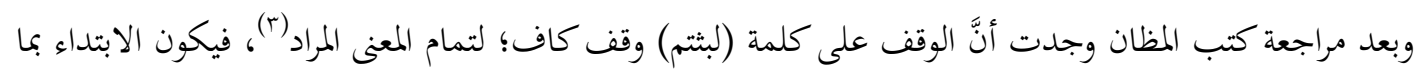

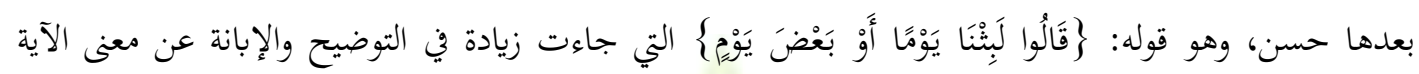
الكريمة.

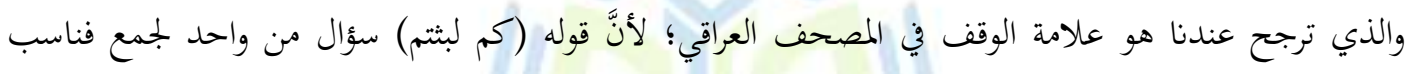

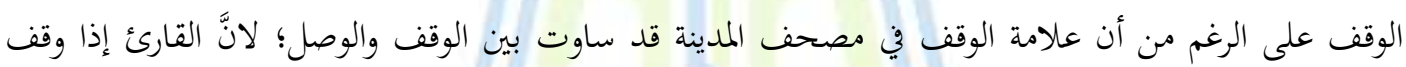

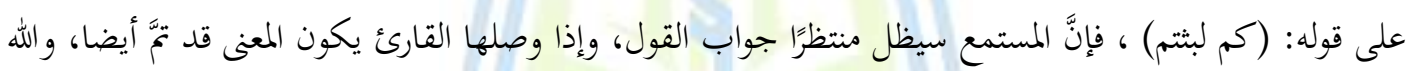
تعالى أعلم. ثالثاً: ظاهرة (َّ مع صلى): وقد جاءت علامة (غَ) في المصحف العراقي بينما جاءت علامة (صلى) في مصحف المدينة في سورة الكهف (V)

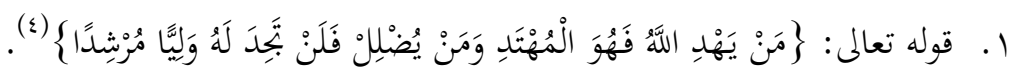

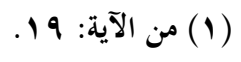

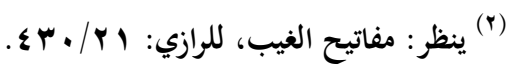

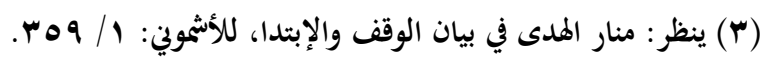

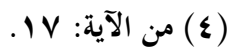

$\varepsilon \vee 0$ 


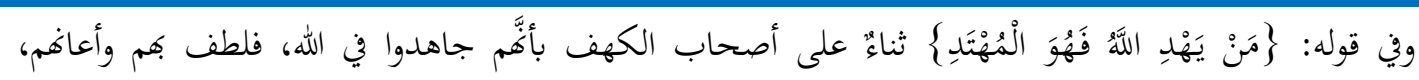

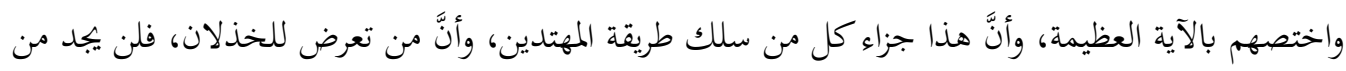
يرشده بعد خذلان الله '(1).

وقد وضعت العلامتان في المصحفين على كلمة (المهتد)، فوضعت علامة () في المصحف العراقي بينما وضعت علامة (صلى) في مصحف المدينة. وبعد مراجعة كتب المظان وجدت أنَّ الوقف على كلمة (المهتد) وقف كاف بالشرط(r)، وقرأ نافع وأبو عمرو بإثبات الياء (المهتدي) وصلاً، وحذفها الباقون وصلا ووقفا، فيكون الوقف عليها والابتداء بما بعدها حسن،

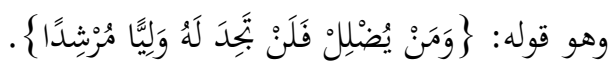
والذي ترجح عندنا هو علامة الوقف في المصحف العراقي لتمام المعنى عند قوله تعالى: (فهو المهتد) ، وإنَّا جاء

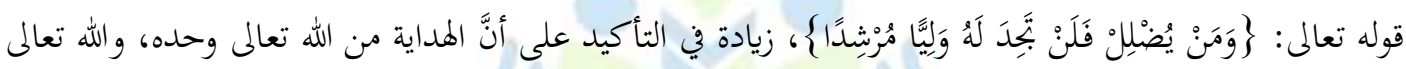
أعلم.

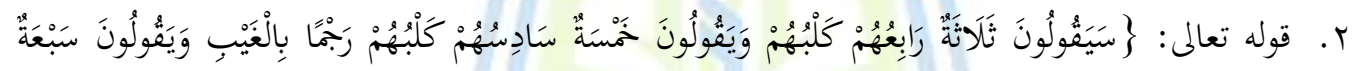

(r)

ذكر الطبري رحمه الله تعالى في معنى الآية: "يقول تعالى ذكره: سيقول بعض الخائضين في أمر الفتية من

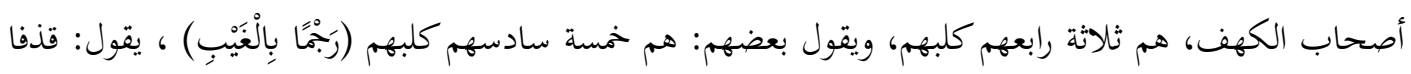

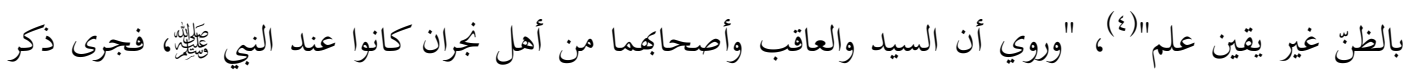

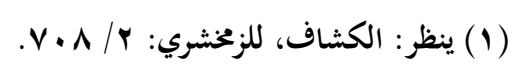

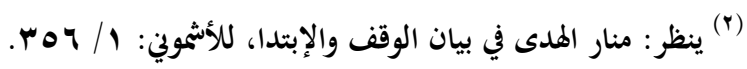
$\sum \vee 7$

$$
\begin{aligned}
& \text { (T) من الآية: بr. }
\end{aligned}
$$

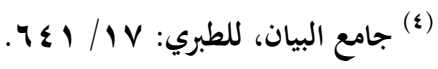


أصحاب الكهف، فقال السيد وكان يعقوبيا: كانوا ثلاثة رابعهم كلبهم، وقال العاقب وكان نسطوريا: كانوا خمسة

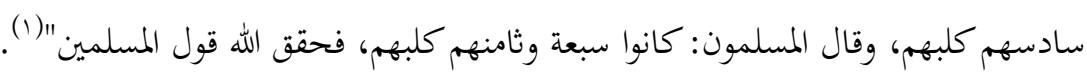
وضع العلماء العلامتان في المصحفين على كلمة (بالغيب)، فوضعت علامة (ج) في المصحف العراقي بينما وضعت علامة (صلى) في مصحف المدينة.

وبعد الرجوع إلى كتب المظان وجدت أنَّ الوقف على كلمة (بالغيب) وقف حسن(r)، فيكون الوقف عليها والابتداء بما بعدها حسن. والذي ترجح عندنا هو علامة الوقف في المصحف العراقي لتمام المعنى عند قوله تعالى: (بالغيب)؛ لأن الله تبارك وتعالى قد وصف القولين الأولين بأنَّهَ رجم بالغيب، أما الثالث فقد جاء بعده استثناء وهو قوله: (ما

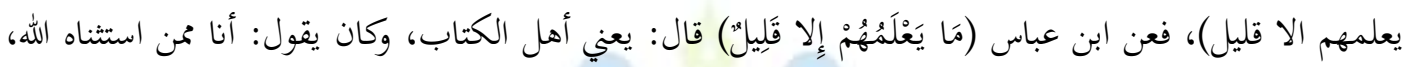
ويقول: عدةم سبعة(؟). والله تعالى أعلم. رابعًا: ظاهرة (لا مع صلى): وقد جاءت علامة (لا) في المصحف العراقي بينما جاءت علامة (๕) في مصحف المدينة في سورة الكهف مرتين، وقد بينا معناهما، وهاتان الآيتان اللتان جاءت فيهما العلامتان:

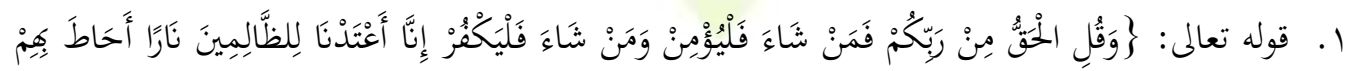

(๕) 
جاء في تفسير قوله تعالى: \}وَمَنْ شَاءَ فَلْيَكْفُر

$$
\text { للتخيير، إذ لا حول لهم ولا قوة إلا بما سبق علمه فيهم (1). }
$$

وقد وضع العلماء علامة (لا) على كلمة (فليكفر) في المصحف العراقي بينما وضعوا علامة الوقف (َّ) على الكلمة نفسها في مصحف المدينة.

وبعد الرجوع إلى كتب المظان وجدت أنَّ الوقف على كلمة (فليكفر) في الآية الكريمة وقف كافٍ (r)،

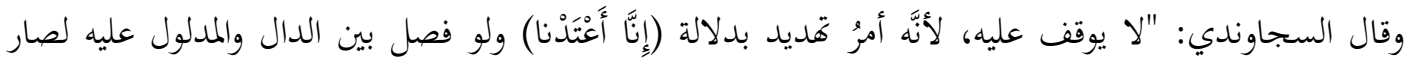
الأمر مطلقا، والأمر المطلق للوجوب فلا يُممل على غيره"(r).

والذي نذهب إليه هو ترجيح علامة الوقف في المصحف العراقي؛ لأنَّ الجملة إنَّا جاءت للتهديد، فلا يُفصل بينها وبين ما بعدها، حتى لا يكون الأمر مطلقاً، فيظن السامع أنَّ الأمر للتخيير، والله تعالى أعلم.

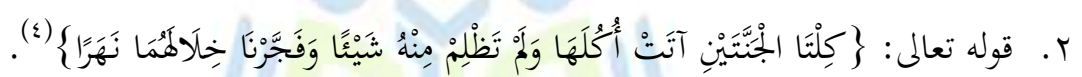

يقول أهل التفسير في معنى قوله (شيئا) أي: تنقص: أي: لم تنقص من الأكل شيئا، ومنه قولم: ظلم فلانٌ

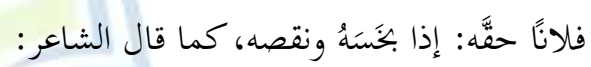

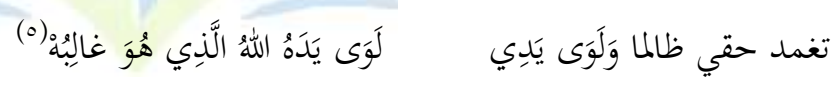

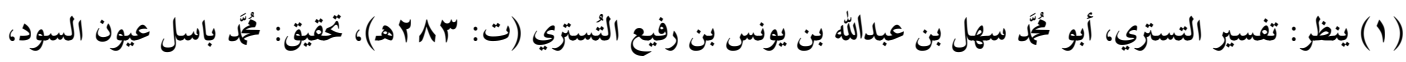

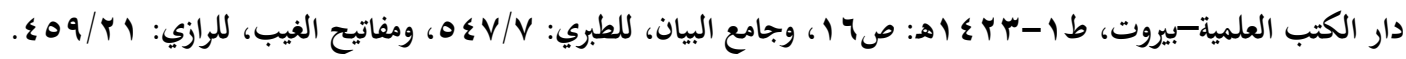

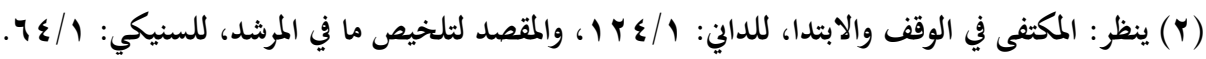

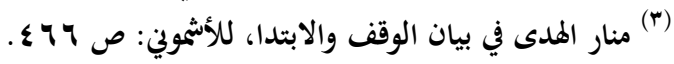

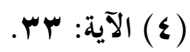

(ه) البيت لفرعان بن الاعرف قاله في ابنه منازل لعقوقه، شرح الحماسة، يجيى بن علي بن يُمَّمَ الشيبانيّ التبريزي، أبو زكريا (ت: $\varepsilon \vee \wedge$

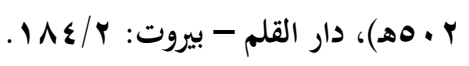




\section{وقد وصف الجنتين بوفاء الثمار وتمام الأكل من غير نقص (1).}

وقيل: الظّلم: هو الثلج، لأنه ينقص سريعاً، وقيل أيضاً: هو ماء آسنُ وطلاوته وبياضه تشنبيهاً له

وقد وضع العلماء علامة (لا) على كلمة (شيئًا) في المصحف العراقي بينما وضعوا علامة الوقف (ع) على الكلمة نفسها في مصحف المدينة.

وبعد الرجوع إلى كتب المظان وجدت أنَّ الوقف على كلمة (شيئا) في الآية الكريمة وقف كافٍ (r)، فيكون

$$
\text { الابتداء بما بعدها وهو قوله: (وفجرنا خلالفما غرا) ابتداء حسن. }
$$

والذي نختاره ترجيح علامة الوقف (َ) في مصحف المدينة التي تساوي بين الوقف والوصل؛ لأنَّ تمام

$$
\text { خامسًا: ظاهرة (زمعل في الجنتين لا يتحصل إلا بوجود الأهار فيها، والله أعلم. }
$$

وقد جاءت علامة (') في المصحف العراقي بينما جاءت علامة () في مصحف المدينة في سورة الكهف مرة واحدة فقط، وقد بينا معنى العلامتين، وهذه الآية التي جاءت فيها العلامتان:

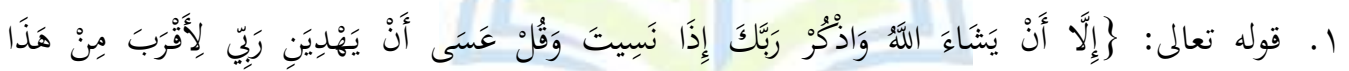

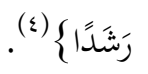

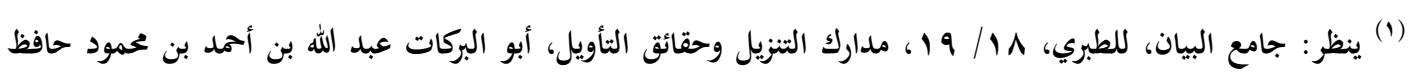

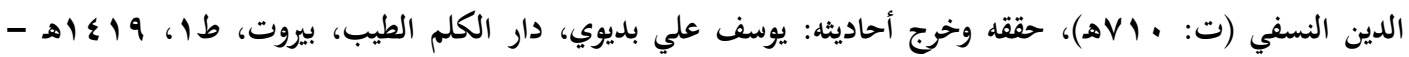

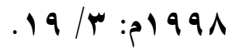

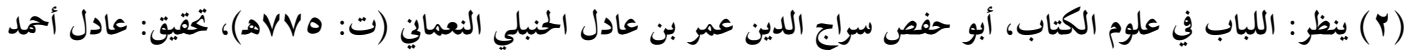

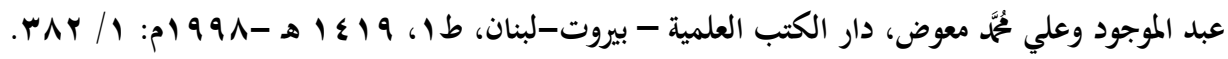

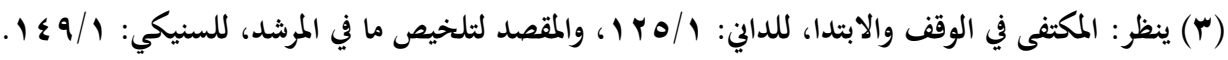

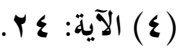
$\leqslant \vee 9$ 


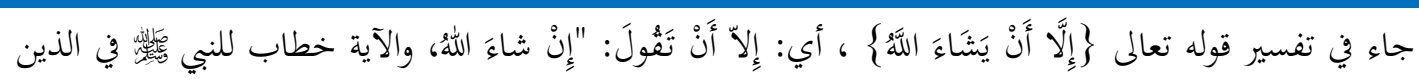
سألوه عن أمر أصحاب الكهف، المسائل التي سألوك عنها أي: لا تقل لهم سأخبركم غدا كما قلت لهؤلاء واستنيت مشيئة الله (1).

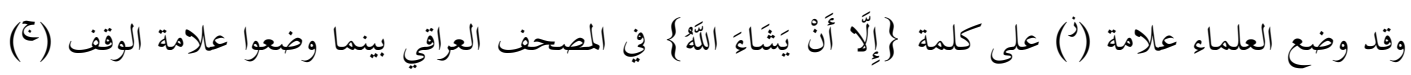
على الكلمة نفسها في مصحف المدينة. وبعد الرجوع إلى كتب المظان وجدت أنَّ الوقف على قوله: $\}$ إلإَّا أَنْ يَشَاءَ اللَّهُ في الآية الكريمة وقف

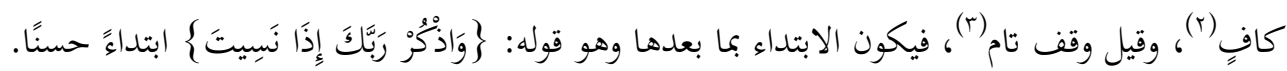

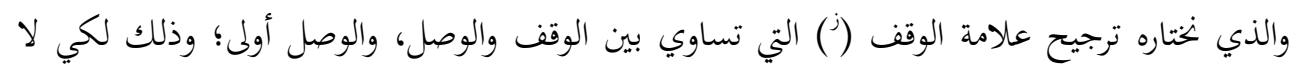

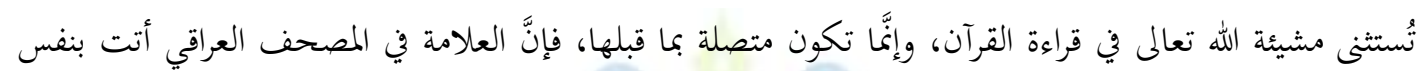
معنى العلامة في مصحف المدينة وزيادة، والله أعلم.

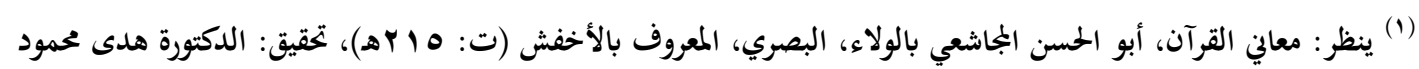

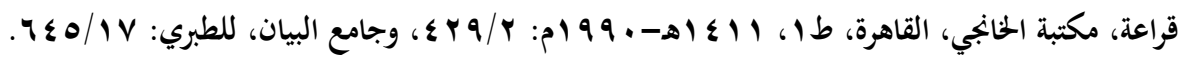

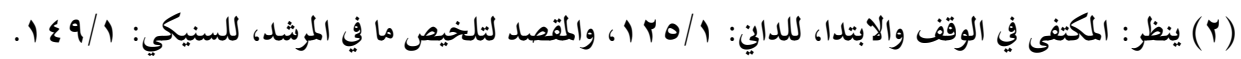

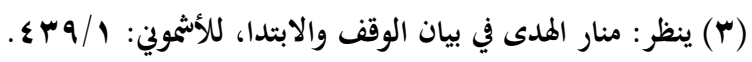
$\varepsilon \wedge$. 


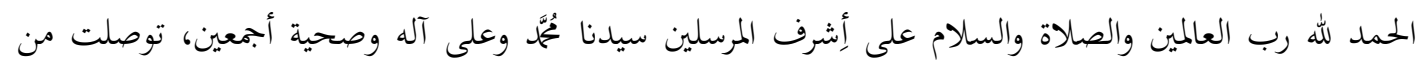

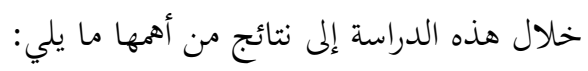

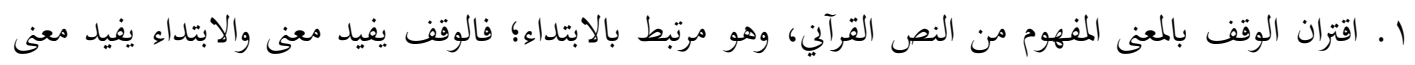

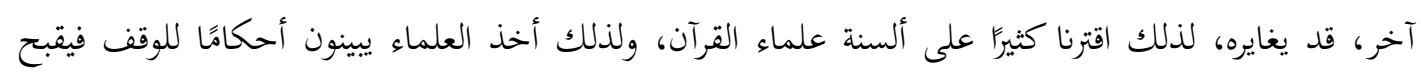

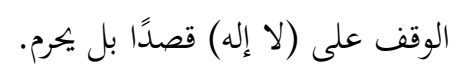

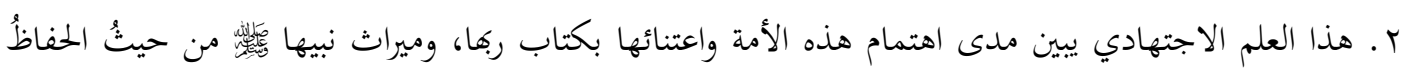

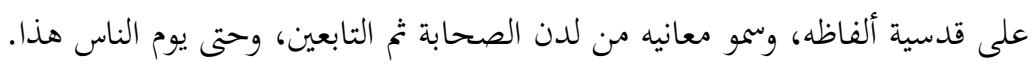

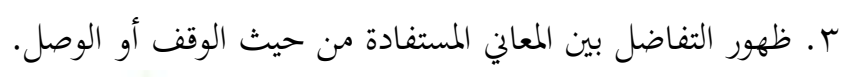
وآخر دعوانا أن الحمد لله رب العلمين لمان لمنين 


\section{الْمَصادر والْمَراجع

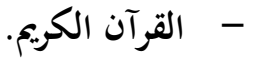

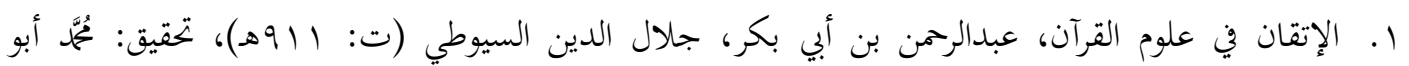
الفضل إبراهيم الميئة المصرية العامة للكتاب، ع9 اهـ- ع و ام. r. الأعلام، لخير الدين الززكلي، الطبعة الخامسة عشر، دار العلم للمالايين-بيروت، ب...T.

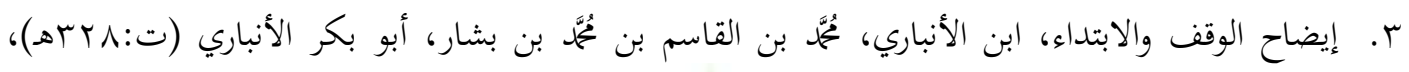

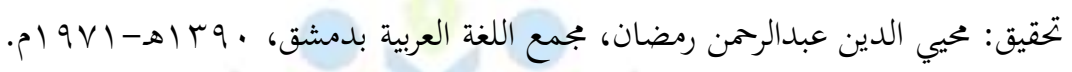

ع. بيان المعاني مرتب حسب ترتيب النزول، عبدالقادر بن ملا حويش السيد عمود آل غازي العاني

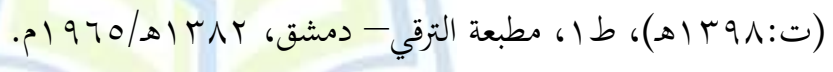

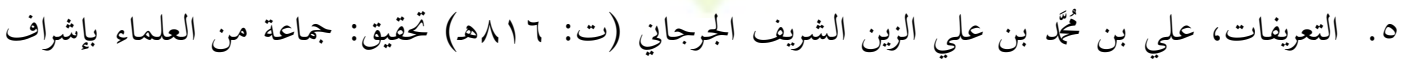

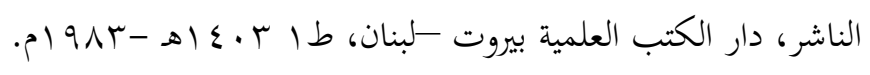

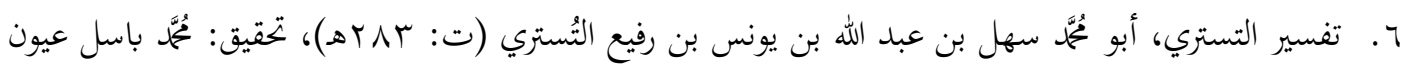

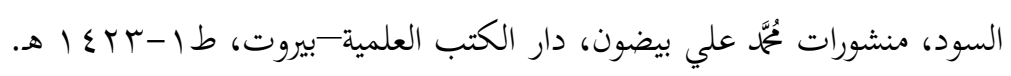

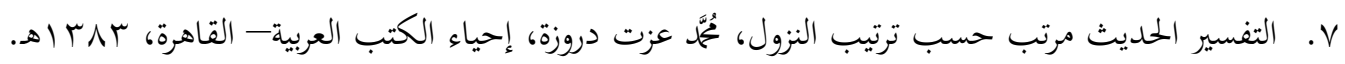


1. جامع البيان في تأويل القرآن، عُمَّمَ بن جرير بن يزيد بن كثير بن غالب الآملي، أبو جعفر الطبري (ت:

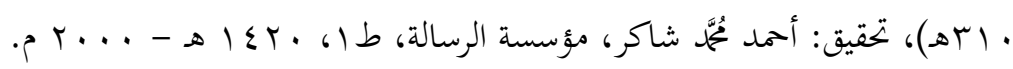

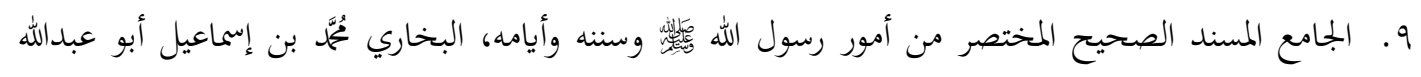
البخاري الجعفي، تحقيق: مُمَّمَ زهير بن ناصر الناصر، طال، دار طوق النجاة/مصورة عن السلطانية بإضافة

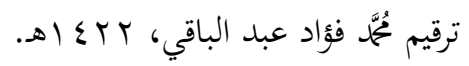

• 1 ـ حدائق الروح والريهان في روابي علوم القرآن، الشيخ يُمَّمَ الأمين بن عبد الله الأرمي العلوي الهرري الشافعي، إشراف ومراجعة: الدكتور هاشم يُمَّم علي بن حسين مهدي، طا، دار طوق النجاة، بيروت - لبنان، $.0 T \cdot 1 / 81 \leq r)$

11 ـ دراسات في علوم القرآن الكريه، الرومي، فهد بن عبدالرممن بن سليمان الرومي، طبا، حقوق الطبع

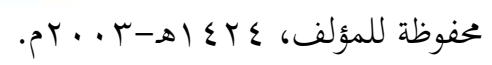

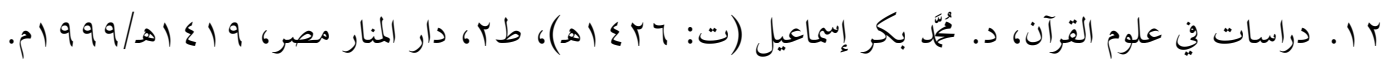
با 1. رسم المصحف وضبطه بين التوقيف والاصطلاحات الحديثة، شعبان يُمَّمَ إسماعيل، طب، دار السلام للطباعة والنشر، بدون تاريخ.

ع ا. روح البيان، إسماعيل حقي بن مصطفى الإستانبولي الحنفي الخلوتي ، المولى أبو الفداء (ت: VV I اله)، دار الفكر - بيروت، بدون.

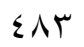


1. سنن أبي داود، أبو داود سليمان بن الأشعث بن إسحاق بن بشير بن شداد بن عمرو الأزدي السِّحسْتاني

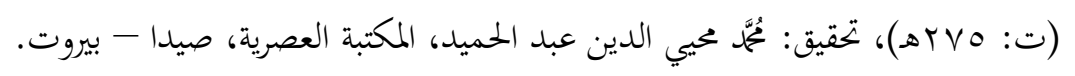

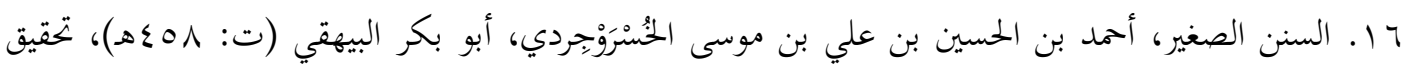

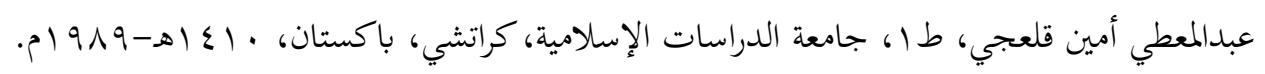

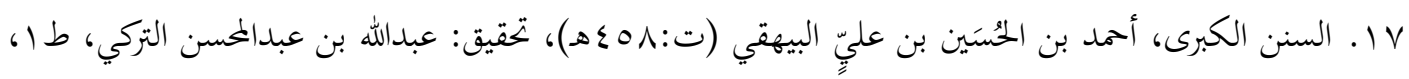

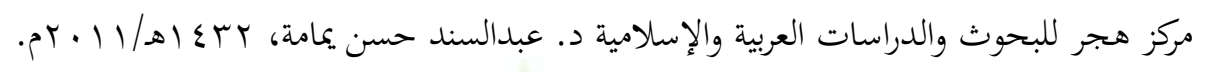
1 ا. شرح الحماسة، يهيى بن علي بن تُمَّمَ الشيبانيّ التبريزي، أبو زكريا (ت: ؟ . هـ)، دار القلم-بيروت. 19. الصحاح تاج اللغة وصحاح العربية، أبو نصر إسماعيل بن مماد الجوهري (ت:بوبه)، تحقيق: أحمد

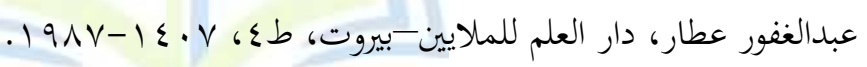

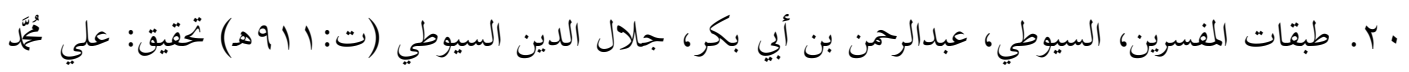
عمر، طا 1، مكتبة وهبة - القاهرة 97 باهـ.

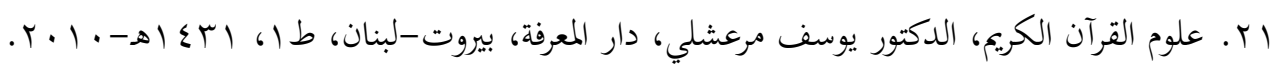

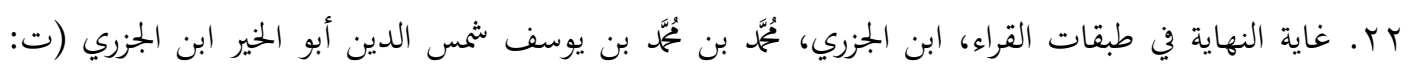

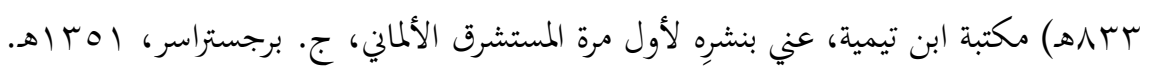


rr. فضل علم الوقف والابتداء وحكم الوقف على رؤوس الآيات، عبد الله علي الميموني، دار القاسم للنشر

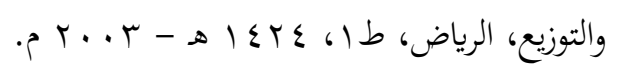

ع r. فقه قراءة القرآن الكريم، صخر، سعيد عبد الجليل يوسف صخر المصري، طا، مكتبة القدسى- القاهرة،

$$
.0199 \vee / 81 \leqslant 11
$$

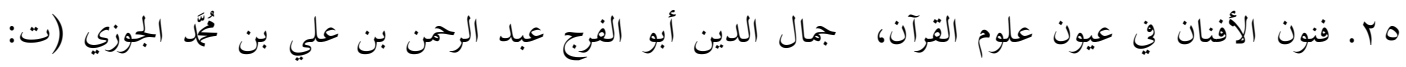

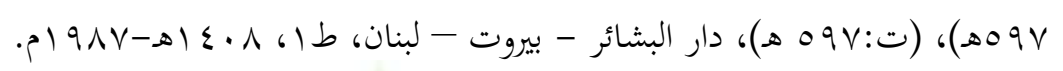

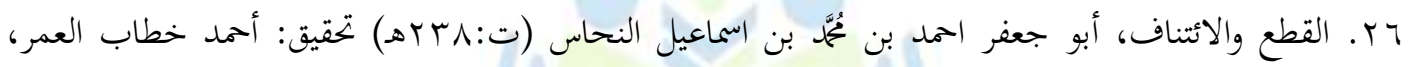

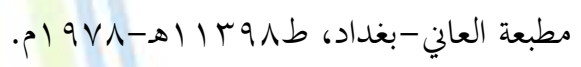

VV. الكشاف عن حقائق غوامض التنزيل، أبو القاسم محمود بن عمرو بن أحمد، الزخشري جار الله (ت:

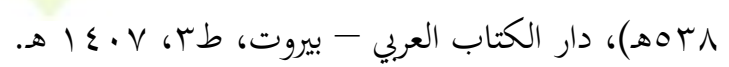

1 ^. اللباب في علوم الكتاب، أبو حفص سراج الدين عمر بن عادل الحنبلي النعماني (ت:

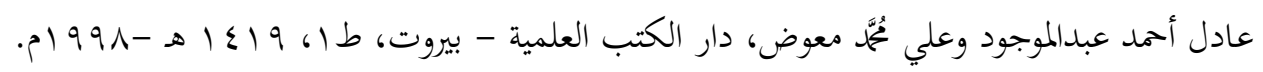

وج. الختسب في تبين وجوه شواذ القراءات والإيضاح عنها، أبو الفتح عثمان بن جني الموصلي (ت: بو بهـ)، وزارة الأوقاف-المجلس الأعلى للشئون الإسلامية، ·ـ بـ اهـ- 999 م. 


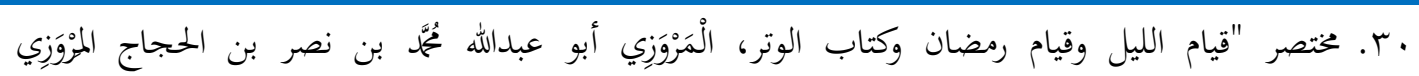

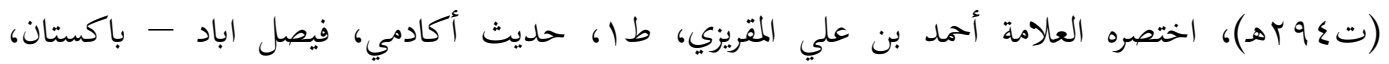
$.619 \Lambda \Lambda / 81 \varepsilon \cdot \Lambda$

آس. مدارك التنزيل وحقائق التأويل، أبو البركات عبد الله بن أحمد بن محمود حافظ الدين النسفي (ت: 1 Iهـ)، حققه وخرج أحاديثه: يوسف علي بديوي، دار الكلم الطيب، بيروت، ط1، 91 1ـ1 هـ - 991 ام. rr. المسند الصحيح المختصر بنقل العدل عن العدل إلى رسول الله ، مسلم، بن الحجاج القشيري النيسابوري (ت: الب آهـ)، تحقيق: عُمَّمَ فؤاد عبدالباقي، دار إحياء التراث العربي-بيروت، بدون تاريخ.

rr. المصنف في الأحاديث والآثار، أبو بكر بن أبي شيبة، عبدالله بن مُحَّم بن إبراهيم بن عثمان بن خواستي العبسي (ت: Oبrrهـ)، تحقيق: كمال يوسف الحوت، طا م، مكتبة الرشد - الرياض، 9.

ع r. معان القرآن، أبو الحسن المجاشعي بالولاء، البلخي ثم البصري، المعروف بالأخفش (ت: 10 بهـ)، تحقيق: الدكتورة هدى محمود قراعة، مكتبة الخانجي، القاهرة، طا، الإـاهـ- - 199 م.

هr. معجم المؤلفين، عمر رضاكحالة، مكتبة المثنى-بيروت، دار إحياء التراث العربي بيروت (د: ط، ت).

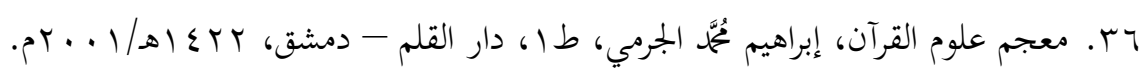


VV. مفاتيح الغيب، أبو عبد الله تُمَّمَ بن عمر بن الحسن بن الحسين التيمي الرازي الملقب بفخر الدين الرازي

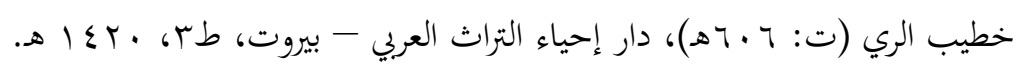

مr. المقدمات الأساسية في علوم القرآن، الجديع، عبداله بن يوسف بن عيسى بن يعقوب اليعوب الجديع

$$
\text { العنزي، ط ا، مركز البحوث الإسلامية ليدز - بريطانيا، r بـ اهـ/ ا . بrم. }
$$

وج. المقصد لتلخيص ما في المرشد في الوقف والابتداء، زكريا بن مُحمّة بن أحمد بن زكريا الأنصاري، السنيكي (ت:

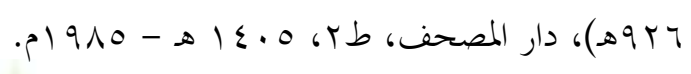

•ــ المكتفَى فيف الوقف والابتدا، عثمان بن سعيد بن عثمان بن عمر أبو عمرو الداني (ت: ع \&هـ)، تحقيق:

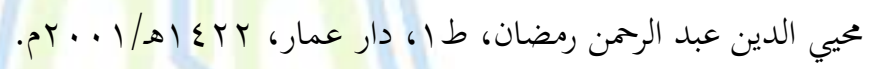

اءـ. منار أحكام قراءة القرآن للشيخ محمود خليل الحصري، سلسلة دراسات في الإسلام، ط. المجلس الأعلى للشؤون الإسلامية، القاهرة العدد ع ال الا.ت.

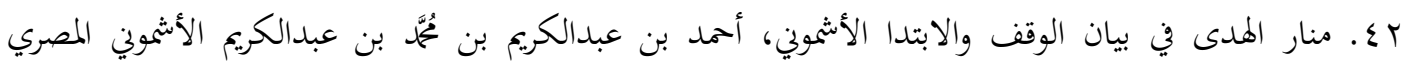

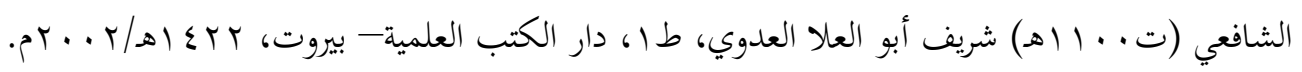

بــ نسخة من المصحف العراقي، طبع وزارة الأوقاف العراقية سنة ا.ـع اهـ/919 ام.

§ ـ نسخة من مصحف المدينة، بجمع الملك فهد لطباعة الصحف الشريف. 
Published by the College of Islamic Sciences at the University of Fallujah ISSN p.p:2708-3993 / ISSN o.I: 2708-4000

هـ. هداية القاري إلى بتويد كلام الباري، عبد الفتاح بن السيد عجمي بن السيد العسس المرصفي المصري الشافعي (ت: 9 • ع (هـ)، مكتبة طيبة، المدينة المنورة، طץ.

بـ ـ الوافي بالوفيات، الصفدي، صلاح الدين خليل بن أيبك بن عبدالله الصفدي (ت:ع ـهـ) تحقيق: أحمد

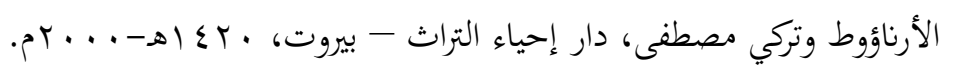

Vـ أوافي في كيفية ترتيل القرآن الكريم، حمد محمود عبدالسميع الشافعي الحفيان، دار الكتب العلمية/بيروت،

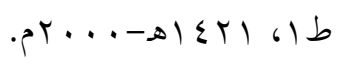

